\title{
Short-Term Microgravity Influences Cell Adhesion in Human Breast Cancer Cells
}

\author{
Mohamed Zakaria Nassef ${ }^{1}$, Sascha Kopp ${ }^{1, *}$, Daniela Melnik ${ }^{1}$, Thomas J. Corydon ${ }^{2,3}{ }^{(D)}$, \\ Jayashree Sahana ${ }^{2}$, Marcus Krüger ${ }^{1}{ }^{1}$, Markus Wehland ${ }^{1}$, Thomas J. Bauer ${ }^{1}$, \\ Christian Liemersdorf ${ }^{4}\left(\mathbb{D}\right.$, Ruth Hemmersbach ${ }^{4}$, Manfred Infanger ${ }^{1}$ and Daniela Grimm ${ }^{1,2,5, *}$ \\ 1 Clinic for Plastic, Aesthetic and Hand Surgery, Otto von Guericke University Magdeburg, \\ 39120 Magdeburg, Germany; mohamed.nassef@med.ovgu.de (M.Z.N.); daniela.melnik@med.ovgu.de (D.M.); \\ marcus.krueger@med.ovgu.de (M.K.); markus.wehland@med.ovgu.de (M.W.); \\ thomas.bauer@med.ovgu.de (T.J.B.); manfred.infanger@med.ovgu.de (M.I.) \\ 2 Department of Biomedicine, Aarhus University, 8000 Aarhus C, Denmark; corydon@biomed.au.dk (T.J.C.); \\ jaysaha@biomed.au.dk (J.S.) \\ 3 Department of Ophthalmology, Aarhus University Hospital, 8200 Aarhus N, Denmark \\ 4 Institute of Aerospace Medicine, Department of Gravitational Biology, German Aerospace Center, \\ 51147 Cologne, Germany; christian.liemersdorf@dlr.de (C.L.); ruth.hemmersbach@dlr.de (R.H.) \\ 5 Gravitational Biology and Translational Regenerative Medicine, Faculty of Medicine and Mechanical \\ Engineering, Otto von Guericke University, 39120 Magdeburg, Germany \\ * Correspondence: sascha.kopp@med.ovgu.de (S.K.); dgg@biomed.au.dk (D.G.); \\ Tel.: +49-391-6721267 (S.K.); +45-871-67693 (D.G.)
}

Received: 11 October 2019; Accepted: 12 November 2019; Published: 15 November 2019

\begin{abstract}
With the commercialization of spaceflight and the exploration of space, it is important to understand the changes occurring in human cells exposed to real microgravity $(r-\mu g)$ conditions. We examined the influence of $r-\mu g$, simulated microgravity (s- $\mu g$, incubator random positioning machine (iRPM)), hypergravity (hyper-g), and vibration (VIB) on triple-negative breast cancer (TNBC) cells (MDA-MB-231 cell line) with the aim to study early changes in the gene expression of factors associated with cell adhesion, apoptosis, nuclear factor "kappa-light-chain-enhancer" of activated B-cells (NF- $\mathrm{KB}$ ) and mitogen-activated protein kinase (MAPK) signaling. We had the opportunity to attend a parabolic flight (PF) mission and to study changes in RNA transcription in the MDA-MB cells exposed to PF maneuvers (29th Deutsches Zentrum für Luft- und Raumfahrt (DLR) PF campaign). PF maneuvers induced an early up-regulation of ICAM1, CD44 and ERK1 mRNAs after the first parabola (P1) and a delayed upregulation of NFKB1, NFKBIA, NFKBIB, and FAK1 after the last parabola (P31). ICAM-1, VCAM-1 and CD44 protein levels were elevated, whereas the NF- $\mathrm{KB}$ subunit p-65 and annexin-A2 protein levels were reduced after the 31st parabola (P31). The PRKCA, RAF1, $B A X$ mRNA were not changed and cleaved caspase-3 was not detectable in MDA-MB-231 cells exposed to PF maneuvers. Hyper-g-exposure of the cells elevated the expression of CD44 and NFKBIA mRNAs, iRPM-exposure downregulated $A N X A 2$ and $B A X$, whereas VIB did not affect the TNBC cells. The early changes in ICAM- 1 and VCAM-1 and the rapid decrease in the NF- $\mathrm{kB}$ subunit p-65 might be considered as fast-reacting, gravity-regulated and cell-protective mechanisms of TNBC cells exposed to altered gravity conditions. This data suggest a key role for the detected gravity-signaling elements in three-dimensional growth and metastasis.
\end{abstract}

Keywords: breast cancer cells; microgravity; hypergravity; cell adhesion; apoptosis; NF-кB 


\section{Introduction}

The GLOBOCAN statistics from 2018 showed that breast cancer is the most common cancer in women and the second leading cause of cancer deaths worldwide [1]. Breast cancer comprises multiple subtypes with characteristic histology, treatability and outcome [2]. Currently, seven molecular subtypes are known [3-6]: luminal A (estrogen receptor positive (ER+)/progesterone receptor positive $(\mathrm{PR}+) /$ androgen receptor positive $(\mathrm{AR}+) /$ human epidermal growth receptor 2 negative (HER2-)/antigen KI67 negative (KI67-)), luminal B (ER+/PR+/AR+/HER2-/KI67+), HER2 enriched (ER-/PR-/HER2+), molecular apocrine (ER-/PR-/AR+/HER2+/KI67+), basal-like/triple-negative (ER-/PR-/AR-/HER2-), normal breast-like (ER+/PR+/HER2-/KI67-) and claudin-low (ER-/PR-/HER2-). Survival of the patients is associated with prognostic factors like tumor size, hormone-receptor-profile and metastases at the time of diagnosis. An onset therapy is the surgical resection of the tumor tissue (lumpectomy or mastectomy). Tumor size and possible metastases to the sentinel lymph node are decisive for the choice of following therapy. Chemotherapy, radiation and anti-hormone therapy, targeted treatment against HER2 and anti-angiogenic therapy are often applied after surgery or in the case of advanced disease stages [7]. Despite the advanced therapy, it is estimated that about 626,679 deaths wordwide will occur from breast cancer per year [1]. Therefore, it is necessary to implement novel ideas to find drug targets and to test new treatment options. This study will focus on the well-described basal-like/triple-negative cancer (TNBC) and will study the TNBC cell line MDA-MB-231 exposed to short-term altered gravity conditions and vibration (VIB) [8]. Using altered gravity conditions in the field of cancer research is not typically the first method to search for target proteins [9], but more than 20 years ago it became clear that cells exposed to microgravity $(\mu g)$ opened an alternative view on cancer cells as they revealed numerous changes like an altered gene expression, protein synthesis and secretion. With the help of simulated microgravity (s- $\mu g$ ) and mass spectrometry, we found novel protein targets involved in cancer [10-13]. A space journey and a longer stay on the International Space Station (ISS) provide altered gravity conditions, which are not found on Earth. On Earth, we can simulate $\mu g$ to some extent by applying rotating devices like a 2D or 3D clinostat, the National Aeronautics and Space Administration (NASA)-developed rotating wall vessel or a random positioning machine (RPM) [14]. Exposure of different cancer cells types to real $(\mathrm{r}-\mu \mathrm{g})$ or simulated (s-) $\mu g$-conditions influences various biological processes, which are of importance in cancer research. Other researchers reported about changes in the morphological phenotype, growth behavior, gene expression, protein content and release, cytoskeletal reorganization, extracellular matrix composition, cell adhesion and others $[14,15]$. One important finding was that in $\mathrm{r}$ - and $\mathrm{s}-\mu g$ various cell types form three-dimensional (3D) aggregates also called multicellular spheroids (MCS), resembling the in vivo situation of tumors much closer than conventional cell cultures [14]. These MCS are of great interest in cancer research to test drugs and to find new treatment targets [16]. An activation of nuclear factor "kappa-light-chain-enhancer" of activated B-cells (NF- $\mathrm{KB}$ ), a proinflammatory transcription factor, was often detected in breast cancer [17]. The "inhibitor of $\kappa B$ " (I $\kappa$ B) proteins include I $\kappa B \alpha, I \kappa B \beta, I \kappa B \gamma, I \kappa B \varepsilon$, and others [18]. Among them, IкB $\alpha$, IкB $\beta$ and IкB $\varepsilon$ are the most important regulators of NF- $\kappa B$ and are of high interest in cancer research and $\mu g$-based research. Interestingly, the NF- $k B$-signaling pathway was significantly altered in FTC-133 cancer cells [19] as well as in MCF-7 breast cancer cells [20] exposed to s- $\mu g$ when MCS were formed. Grosse et al. described an increase in NF-kB p65 protein, when cells were exposed to s- $\mu g$ on an RPM [19]. This discovery was in concert with findings by Kopp et al., who described an activation and increase in NF- $K B$ and associated molecules in MCF-7 cells exposed to the RPM [20]. Through drug-initiated NF- $\mathrm{kB}$ inhibition, they were able to reduce the formation of MCS. As it is not clear when NF- $\mathrm{B}$ B signaling is triggered during MCS formation, we exposed MDA-MB-231 breast cancer cells to $r-\mu g$ during a parabolic flight campaign (PFC).

The principal aim of this study was, first, to investigate the early phases of $r-\mu g$ achieved by PF maneuvers on TNBC cells and to test whether there is a link between factors of apoptosis, changes in NF- $\mathrm{KB}$ signaling and cell adhesion. The second aim was to study VIB and hyper- $g(1.8 g)$ effects on the MDA-MB-231 cells. In a third approach, we exposed the MDA-MD-231 cells to an incubator RPM (iRPM) 
for $2 \mathrm{~h}$ to compare the effects of $\mathrm{s}-\mu g$ with those from $\mathrm{r}-\mu g$. Afterwards, we performed quantitative polymerase chain reaction (qPCR) focusing on genes involved in NF- $\mathrm{kB}$ signaling, cell adhesion and MAPK signaling as well as apoptosis. Furthermore, the molecular biological results were finally evaluated by STRING (Search Tool for the Retrieval of Interacting Genes/Proteins) analyses to visualize the mutual regulation and interactions of genes and proteins examined in this study.

\section{Results}

\subsection{Viability Staining}

To examine whether the MDA-MB-231 cells were viable after the VIB-, hyper-g-, and iRPM-exposure, a terminal deoxynucleotidyl transferase dUTP nick end labeling (TUNEL) assay for the detection of DNA fragmentation was performed to measure the amount of apoptotic cells (Figure 1). Comparing ground controls at Earth's normal gravity $(1 g)$, VIB, $1.8 g$ hyper- $g$ (comparable to the hyper- $g$ exposure on the PFC), and iRPM cell samples, the cytoplasm was evenly stained green, while the nucleus showed no green staining. In contrast, the positive control, which was treated with DNase prior to the staining procedure, presents an intensive green staining of the nucleus. This finding shows, that altered gravity conditions or VIB did not induce apoptosis in MDA-MB-231 cells (Figure 1).

\subsection{Nuclear Factor "Kappa-Light-Chain-Enhancer" of Activated B-Cells (NF-kB) Signaling Factors in} Triple-Negative Breast Cancer Cells during Altered Gravity Conditions

To verify the influence of PF maneuvers on factors involved in the NF- $\mathrm{KB}$-signaling pathway, the gene expression pattern of NF- $\mathrm{KB}$ signaling factors was determined in MDA-MB-231 cells (Figure 2). As a PF comprises different conditions beside microgravity like hyper- $g(1.8 g)$, and VIB, these factors had been additionally tested to isolate the effects derived from the exposure to $\mu g$ (Figure 3).

The major factors of the NF- $\kappa B$-signaling pathway are NF- $\kappa B$ subunits $\mathrm{p} 105 / 50, \mathrm{p} 100 / 52$ and $\mathrm{p} 65$ (NFKB3, RELA) of which their corresponding genes are NFKB1, NFKB2 and NFKB3.

While the gene expression of NFKB1 (P31, up-regulation) (Figure 2A) and NFKB3, (RELA; P1, up-regulation, Figure 2C) are significantly changed after the PF conditions, VIB-, $1.8 \mathrm{~g}$ - and iRPM-exposure had no significant impact on these genes. The NFKB2 mRNA was not altered in any experimental condition (Figure 2B, Figure 3C,D). In contrast, the Western blot analyses of NF- $\mathrm{kB}$ p65 protein presented a significant reduction after P1 and P31 (Figure 2D).

The NF- $\mathrm{kB}$-signaling pathway is modulated by its inhibitors NF-kB-inhibitor-alpha, -beta and -epsilon (NFKBIA, NFKBIB, NFKBIE) and the NF- $\mathrm{BB}$ essential modulator (IKBKG, NEMO). In the case of NFKBIA, NFKBIB and NFKBIE (Figure 2E,G,H) gene expression, a significant upregulation was only found for NFKBIA and NFKBIB after P31 compared to their corresponding controls. The NFKBIA mRNA was differentially expressed by hyper- $g$ (Figure 3G). Protein analyses revealed no significant change in IкB $\alpha$ and NEMO (Figure 2F,J). The NFKBIE and IKBKG gene expressions (Figure 2H,I) were not altered in any of the experimental conditions (Figure $3 \mathrm{~K}-\mathrm{N}$ ). 


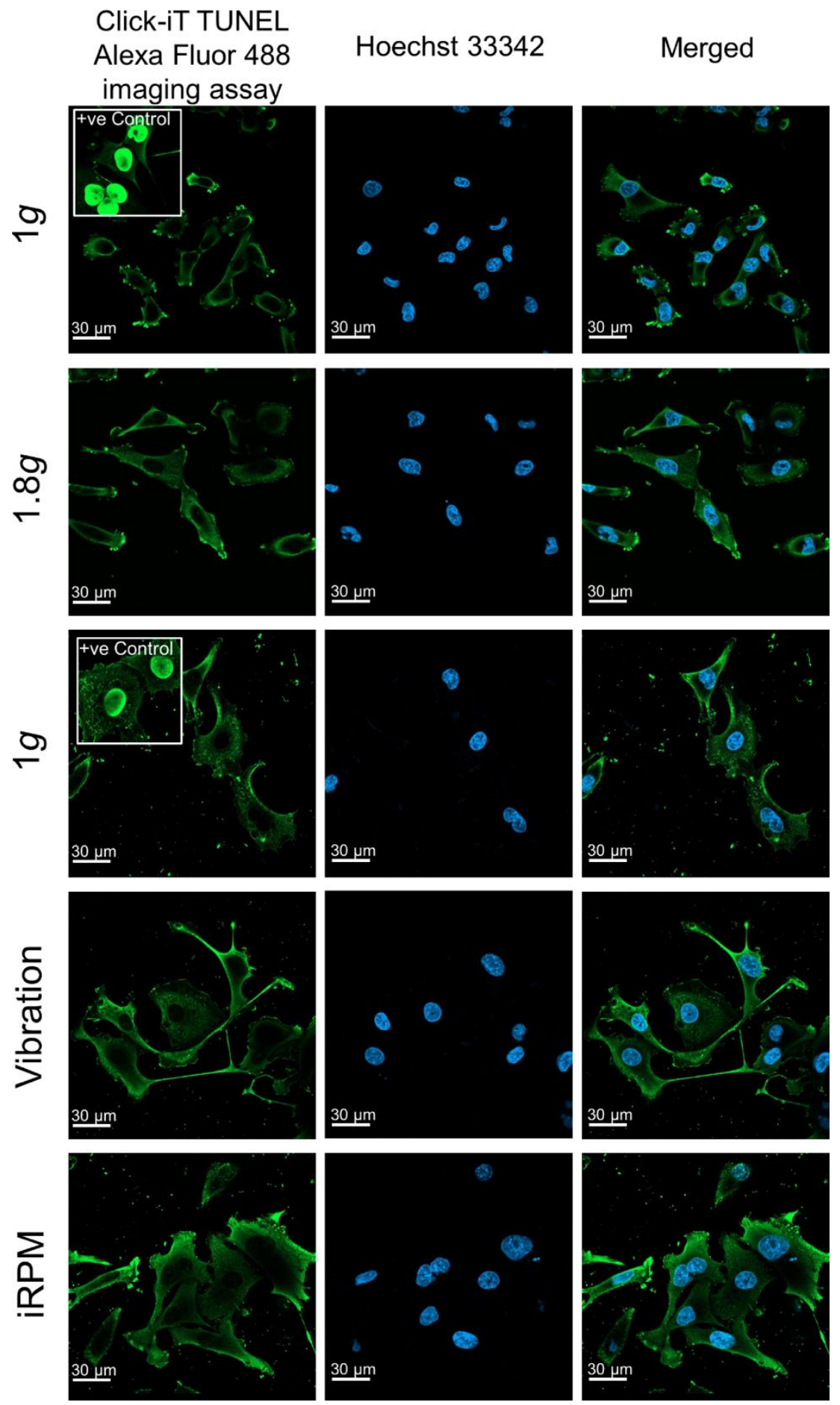

Figure 1. Click-IT terminal deoxynucleotidyl transferase dUTP nick end labeling (TUNEL) assay performed on MDA-MB-231 cells exposed to $1 g, 1.8 \mathrm{~g}$ hyper- $g$, vibration (VIB) and the incubator random positioning machine (iRPM). Green staining indicates free fluorophores in the cytoplasm in all images with the exception of the positive control. In the positive control, samples have been pretreated with DNase to induce DNA fragmentation, which is visualized by an enrichment of the fluorophores in the nucleus. Blue staining highlights the cells' nuclei. Green stained nuclei present apoptotic cells as shown in the inserted positive controls. None of the applied experimental approaches had induced apoptosis in the cells. 

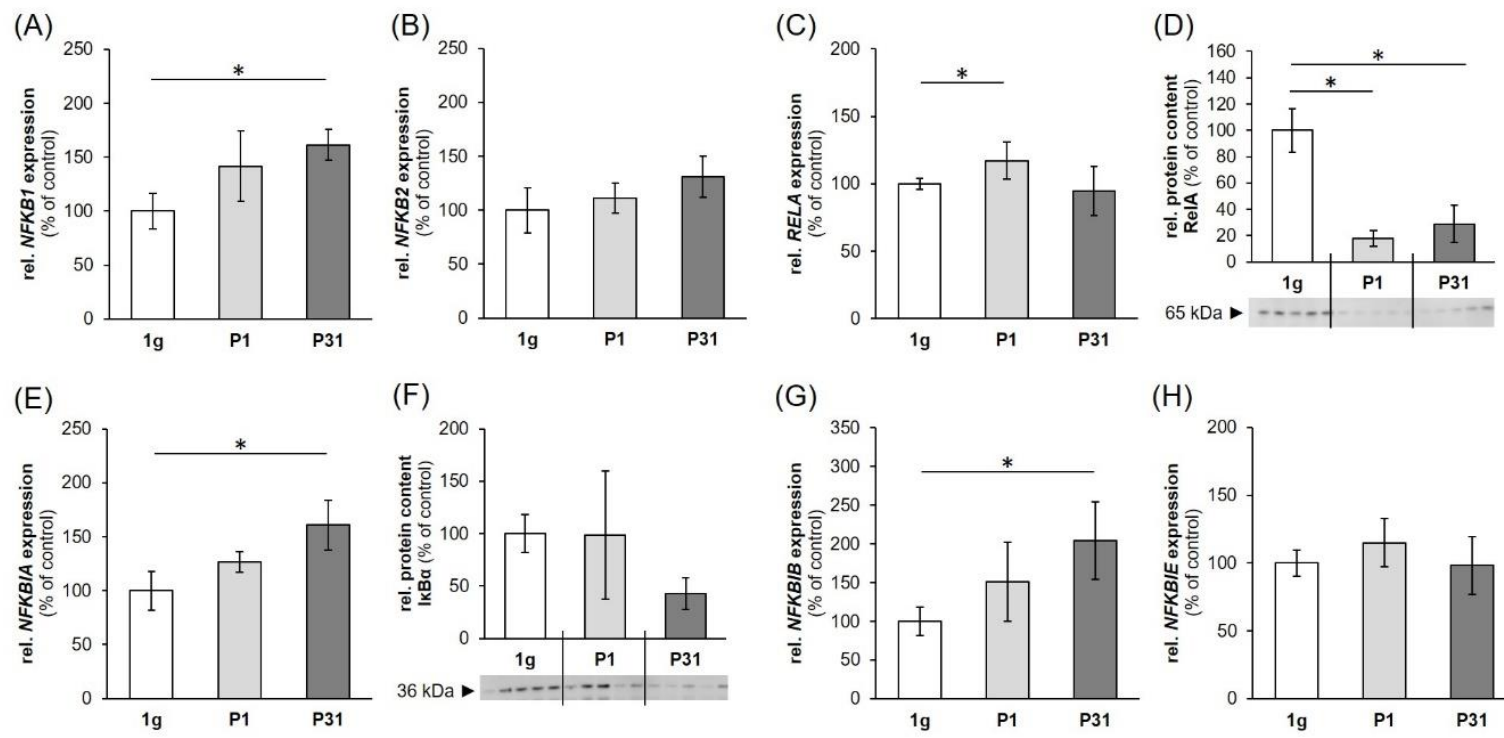

(F)
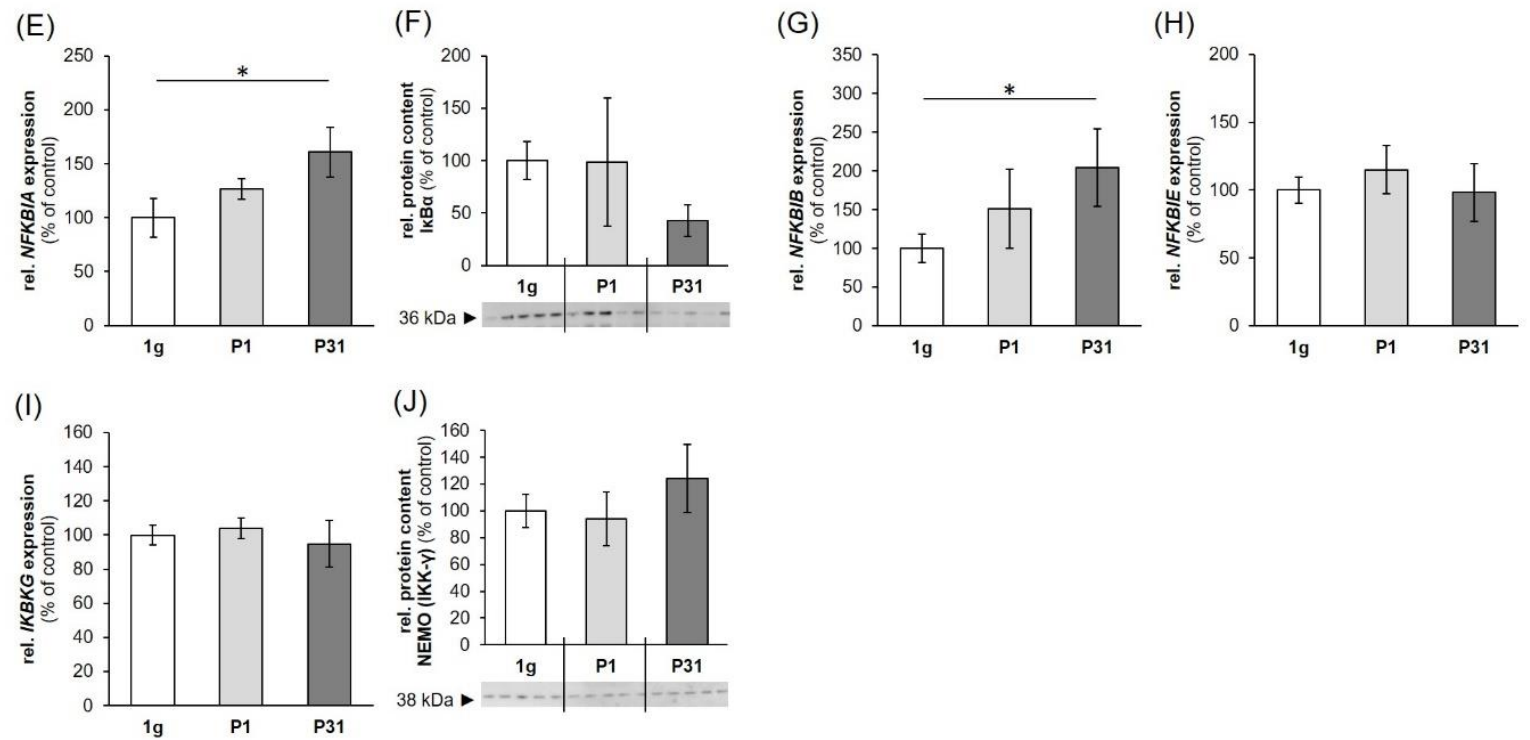

Figure 2. Influence of short-term microgravity on the gene expression: (A) NFKB1, (B) NFKB2, (C) RELA, (E) NFKBIA, (G) NFKBIB, (H) NFKBIE, (I) IKBKG and protein content: (D) RelA, (F) IKB $\alpha$ (J) NEMO; of NF- $\mathrm{KB}$ signaling factors. $n=5$; The data are given as mean \pm standard deviation. ${ }^{*} p<0.05$ vs. $1 \mathrm{~g}$-control. 
(A)

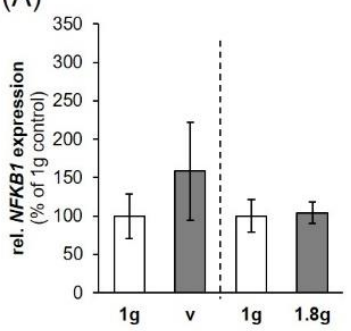

(E)

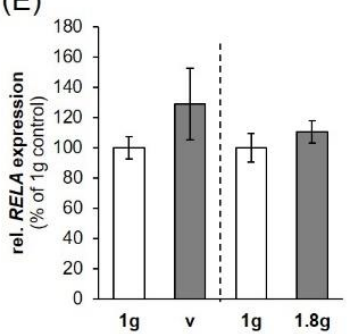

(I)

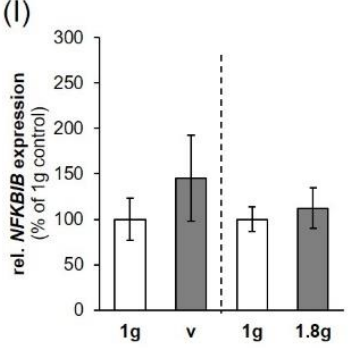

(M)

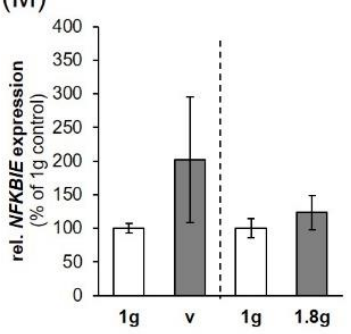

(B)

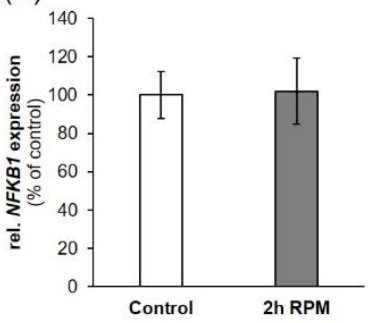

(F)

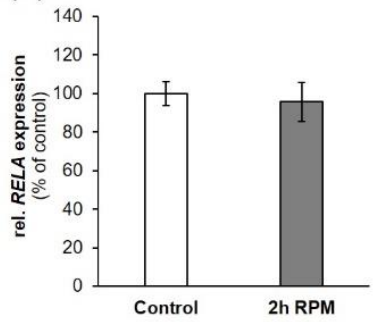

(J)

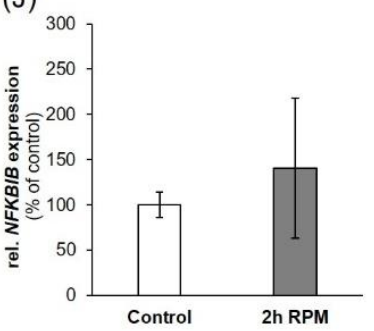

(N)

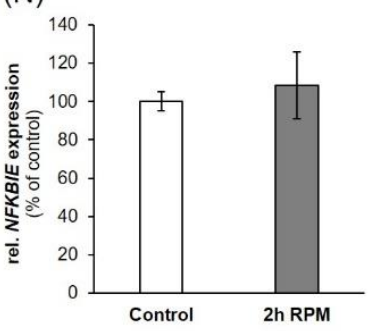

(C)

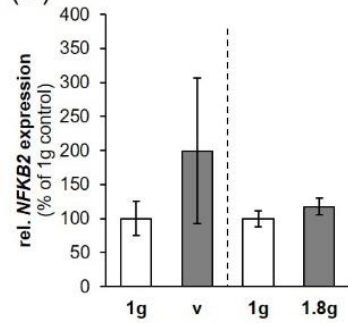

(D)

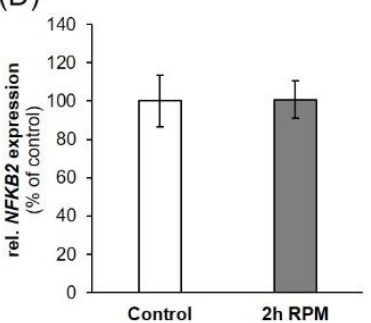

(G)

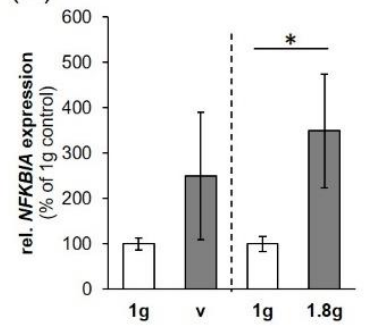

(H)

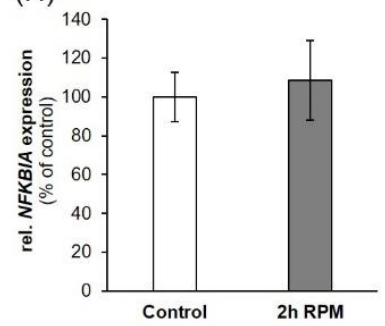

(L)
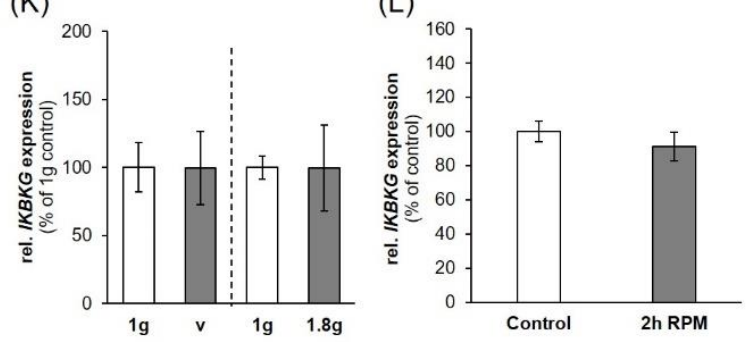

Figure 3. Influence of VIB (V), hyper- $g$ and iRPM-exposure on the gene expression of NF- $\mathrm{kB}$ signaling factors: (A,B) NFKB1, (C,D) NFKB2, (E,F) RELA, (G,H) NFKBIA, (I,J) NFKBIB, (K,L) IKBKG, $(\mathbf{M}, \mathbf{N})$ NFKBIE. $n=5$. The data are given as mean \pm standard deviation. ${ }^{*} p<0.05$ vs. corresponding $1 \mathrm{~g}$-controls. The dashed vertical line seperates two independent experiments.

\subsection{Expression of Factors Belonging to the Biological Process of Apoptosis}

Caspase 3 is a major factor in apoptosis [21]. Gene expression of CASP3 was significantly upregulated after P1 and P31 (Figure 4A) while being not regulated after exposure to vibration and the RPM (Figure 5A,B). Measuring the cleaved caspase-3 protein by Western blot analysis and could not detect any active caspase-3, whereas the positive control colon cancer cells CX+ exerted a strong positivity [21] (Figure 4B).

The gene expression of ANXA1 (Figure 4C, Figure 5C,D) was not significantly changed during any of the experimental procedures. ANXA2 mRNA expression showed a similar behavior (Figure 4D, Figure 5E) except a downregulation after 2h of RPM exposure (Figure 5F). ANXA2 (annexin A2) protein (Figure 4E) was first significantly increased after P1 and then re-adapted after P31, which is in agreement with the data obtained after a two-hour iRPM-exposure of the MDA-MB-231 cells (Figure 5F). In addition, the $B A X$ mRNA was not differentially regulated (Figure 4F, Figure 5I,J), but BCL2 mRNA 
was reduced at both time points (Figure $4 \mathrm{G}$ ). Finally, the BAX mRNA was not altered by VIB and hyper- $g$, but signicantly reduced in MDA-MB-231 cells exposed to the iRPM (Figure 5G,H).

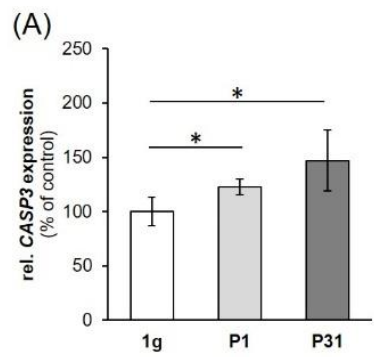

(D)

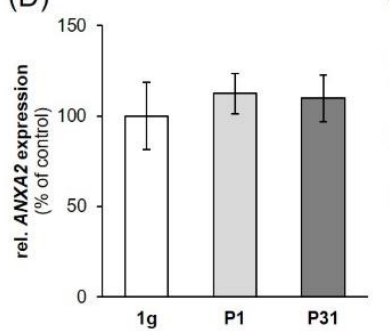

(B)

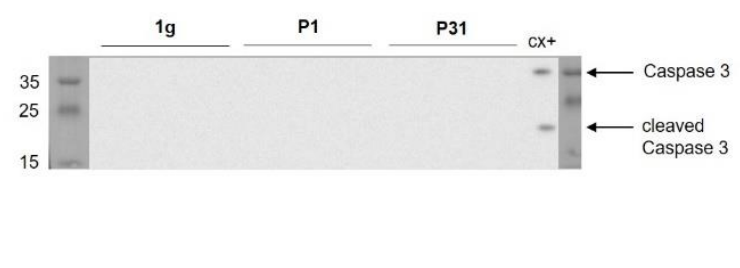

(E)

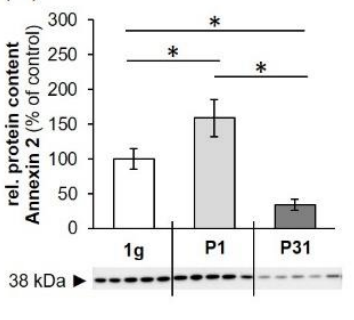

(F)

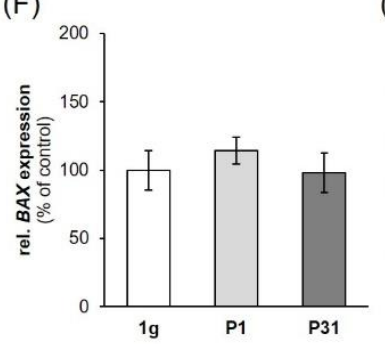

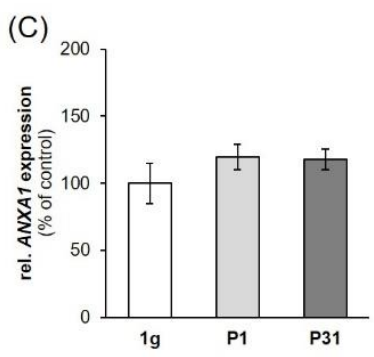

(G)

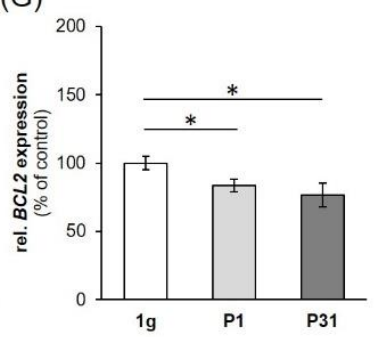

Figure 4. Influence of short-term microgravity on the gene expression: (A) CASP3, (C) ANXA1, (D) ANXA2, (F) BAX, (G) BCL2; and protein content (B) caspase 3, (E) annexin 2 regulators of apoptosis. The data are given as mean \pm standard deviation. ${ }^{*} p<0.05$ vs. $1 g$-control. $\mathrm{CX}+$ colon cancer cells served as positive control for programmed cell death.

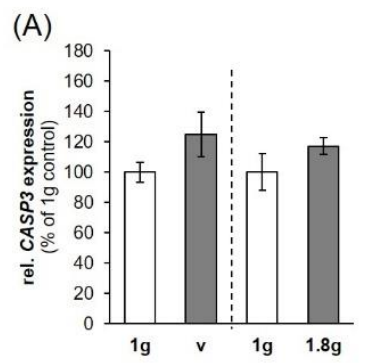

(E)

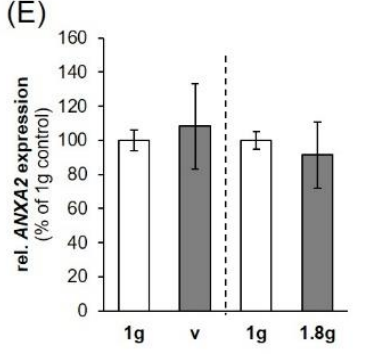

(I)

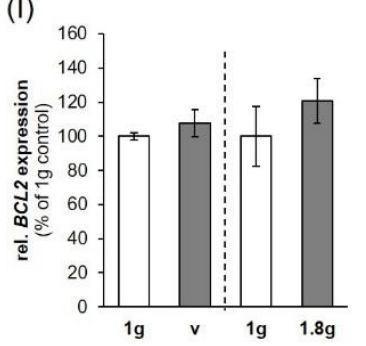

(B)

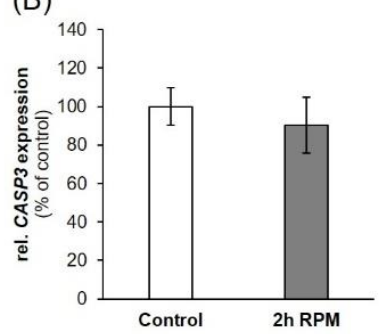

(F)

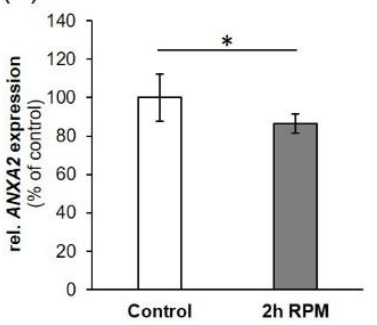

(J)

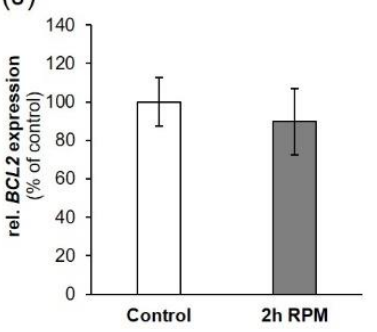

(C)

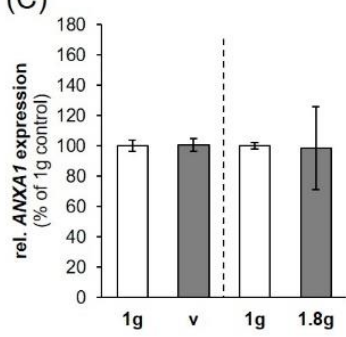

(G)

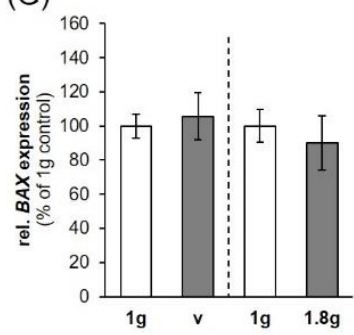

(D)

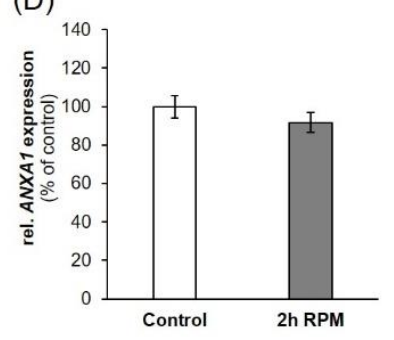

(H)

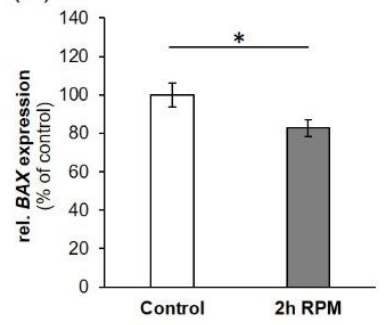

Figure 5. Influence of a VIB (V), hyper-g and iRPM-exposure on the gene expression of apoptosis signaling factors: $(\mathbf{A}, \mathbf{B}) C A S P 3,(\mathbf{C}, \mathbf{D})$ ANXA1, (E,F) ANXA2, (G,H) BAX, (I, J) BCL2. $n=5$. The data are given as mean \pm standard deviation. ${ }^{*} p<0.05$ vs. $1 g$-control. 


\subsection{Regulation of Cell Adhesion Molecules in Triple-Negative Breast Cancer (TNBC) Cells}

The ICAM1 gene expression was significantly upregulated after one parabola. Although our data seem to hint towards an additional upregulation after 31 parabolas, the high variability of the measurements interfered with the statistical analysis (Figure 6A). ICAM1 protein was significantly reduced after the first parabola and increased after 31 parabolas (Figure 6B). We did not observe changes in the VCAM1 gene expression (Figure 6C), while VCAM-1 protein levels were significantly elevated after one and 31 parabolas compared to static $1 g$-controls (Figure 6D).

SPP1 gene expression was found to be significantly enhanced compared to the levels after one parabola, but not to $1 \mathrm{~g}$-controls (Figure 6E). Osteopontin protein expression on the other hand was significantly downregulated compared to static controls after both one and 31 parabolas (Figure 6F).

Finally, the CD44 gene expression showed a constant increase over the course of the experiment, with significant rises after one parabola vs. $1 g$-controls and 31 parabolas vs. $1 g$-controls and levels after one parabola (Figure 6G). CD44 protein levels followed the same tendency with significant increases compared to static controls for both one and 31 parabola samples (Figure $6 \mathrm{H}$ ).

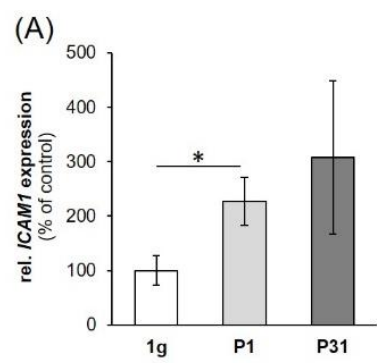

(B)

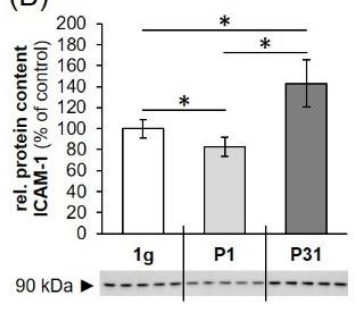

(E)

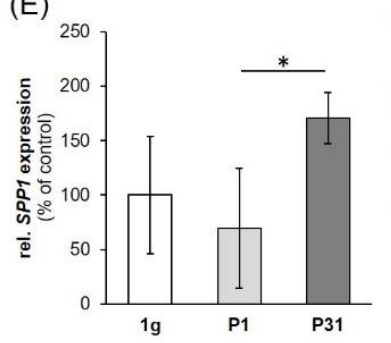

(F)

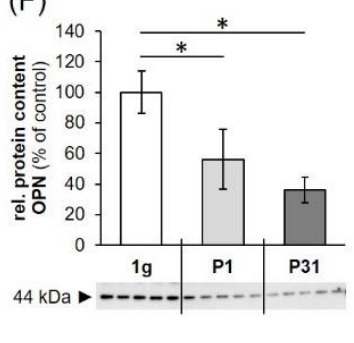

(C)

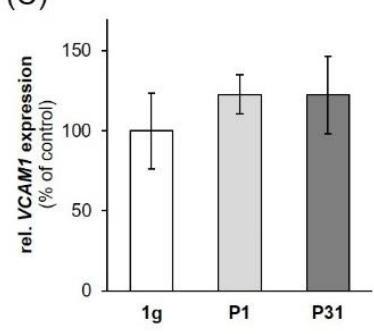

(G)

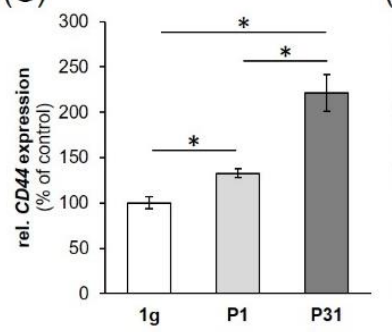

(D)

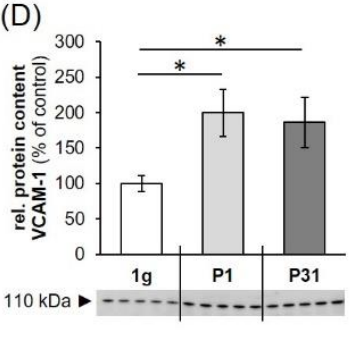

( $\mathrm{H})$

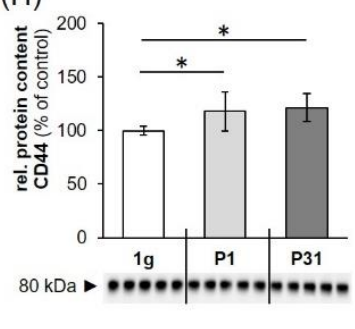

Figure 6. Expression of genes: (A) ICAM1, (C) VCAM1, (E) SPP1, (G) CD44; and proteins: (B) ICAM-1, (D) VCAM-1, (F) OPN, (H) CD44 involved in cell adhesion. 1 g: ground control; P1: parabola 1; P31: parabola 31. The data are given as mean \pm standard deviation. ${ }^{*} p<0.05$ vs. $1 g$-control; ${ }^{* *} p<0.01$ vs. $1 \mathrm{~g}$-control.

ICAM1, VCAM1, and SPP1 were not significantly regulated after VIB, hyper-g- or iRPM-exposure (Figure 7A-F). The CD44 gene expression, on the other hand, was significantly enhanced under conditions of $1.8 \mathrm{~g}$ hyper- $\mathrm{g}$, but remained unchanged by VIB- and iRPM-exposure (Figure 7G,H).

2.5. Factors of the Mitogen-Activated Protein Kinase (MAPK) Signaling Pathway Known to be Involved in Cancer Progression and Metastasis

First, we determined the gene expression of PRKCA (protein kinase $\mathrm{C}$ alpha, PKC $\alpha$ ). The PRKCA mRNA was not significantly upregulated after the 31st parabola compared with corresponding $1 g$-samples (Figure 8A). 


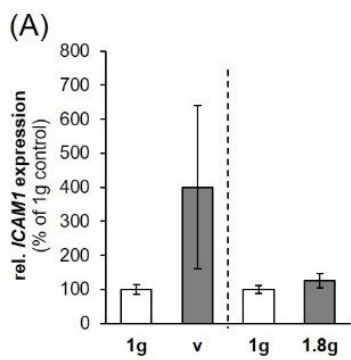

(E)

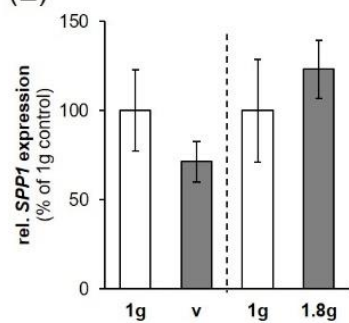

(B)

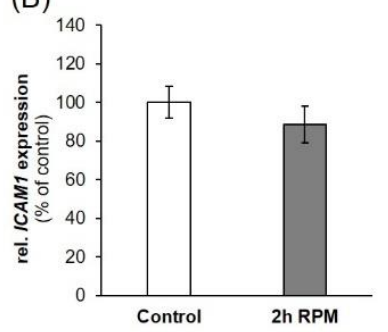

(F)

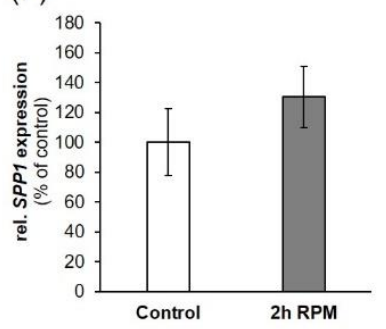

(C)

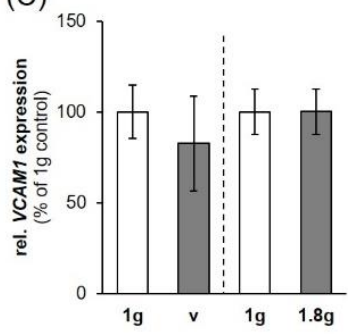

(G)

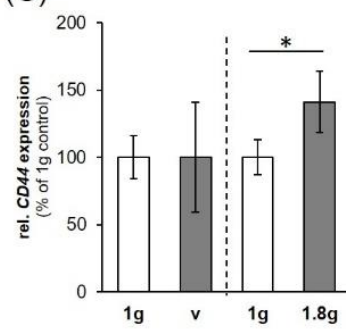

(D)

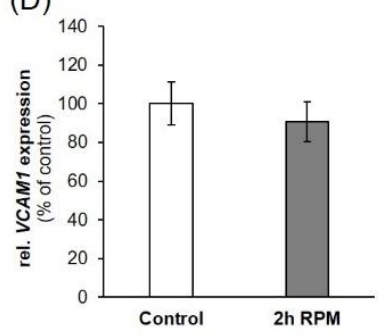

(H)

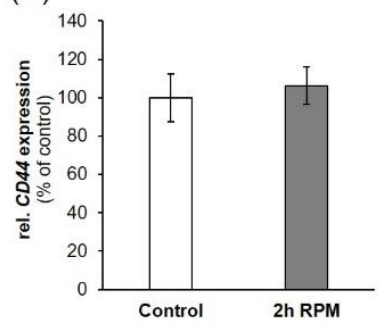

Figure 7. Influence of a VIB (V), hyper- $g$ and iRPM-exposure on the gene expression of cell adhesion signaling factors: (A,B) ICAM1, (C,D) VCAM1, (E,F) SPP1, (G,H) CD44. 1 g: ground control; V: $2 \mathrm{~h}$ of vibration; $1.8 \mathrm{~g}: 2 \mathrm{~h}$ of hyper- $g$. The data are given as mean \pm standard deviation. ${ }^{*} p<0.05$ vs. $1 \mathrm{~g}$-control.

(A)

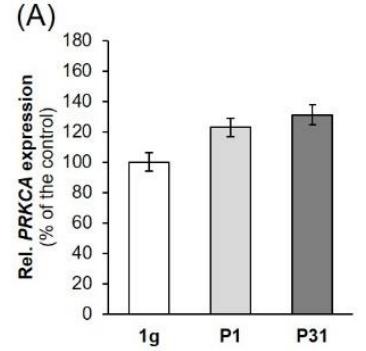

(E)

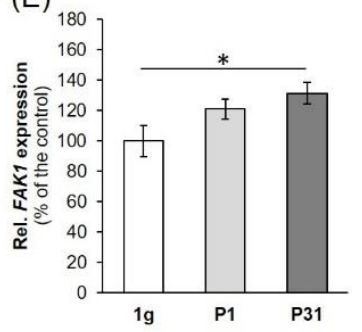

(B)

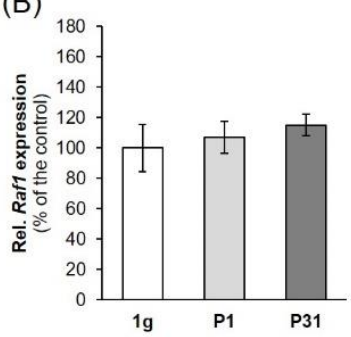

(F)

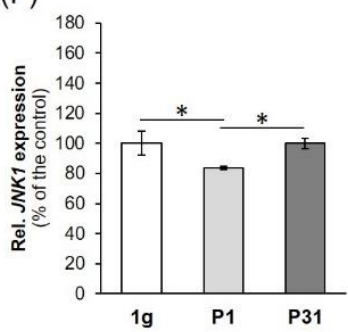

(C)

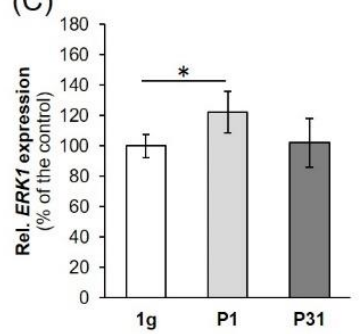

(D)

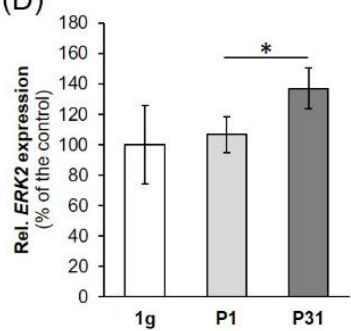

Figure 8. Expression of genes: (A) PRKCA, (B) Raf1, (C) ERK1, (D) ERK2, (E) FAK1, (F) JNK1, involved in cancer progression and metastasis. $1 \mathrm{~g}$ : ground control; P1: parabola 1; P31: parabola 31. The data are given as mean \pm standard deviation. ${ }^{*} p<0.05$ vs. $1 g$-control.

Then we focused on RAF1 (RAF proto-oncogene serine/threonine-protein kinase). RAF1 remained unchanged by PF maneuvers (Figure $8 \mathrm{~B}$ ). Afterwards, we measured the ERK1 (extracellular signal-regulated kinase 1) (Figure 8C) and ERK2 (extracellular signal-regulated kinase 2) (Figure 8D) gene expression. The ERK1 gene expression was significantly up-regulated after the first parabola compared to $1 \mathrm{~g}$-samples (Figure $8 \mathrm{C}$ ). The ERK2 mRNA was significantly elevated after the 31st parabola compared with P1 r- $\mu g$-samples (Figure $8 \mathrm{D}$ ). There is a direct interaction between $E R K 1,2$ and FAK1 (focal adhesion kinase 1 also known as PTK2 (protein tyrosine kinase 2)). The FAK1 mRNA was significantly up-regulated after P31 compared to $1 \mathrm{~g}$-samples (Figure 8E). 
In a next step we measured the $M A P K 8$ (mitogen-activated protein kinase 8) mRNA also called JNK1 (c-Jun N-Terminal Protein Kinase 1) (Figure 8F). JNK1 was down-regulated after P1 and was not significantly changed after P31, indicating a rapid short-term effect of microgravity.

\subsection{Search Tool for the Retrieval of Interacting Genes/Proteins (STRING) Analysis}

The various genes analyzed by qPCR were investigated in regard to their possible interaction and mutual expression dependence. A STRING/EMBL analysis of these items represented in molecule action mode is shown in Figure 9. It can be seen that the nuclear factors, whose expression was analyzed, are regulating each other very strongly, while the remaining items form a loose network. RELA, NFKB1 and NFKB2, which represent three of the five members of the transcription factor NF- $\kappa B$ family are strictly controlled at various levels [22]. Their activity is regulated by interaction with each other, with inhibitors such as NFKBIA, NFKBIB, NFKBIE and with kinases such as IKBKB (NEMO). The regulation occurs at various levels including the gene expression level. For example, NFKB1 and RELA form protein heterodimers and are also associated in the regulation of their expression [23]. Moreover, RELA and VCAM1 are upregulated after an injury of an artery, while NFKBIA is down-regulated [24] and if annexin A1 is upregulated, it forms a complex with IKFKG that activates NFKB [25]. On the other hand, the nuclear factors control the transcription of other genes. A target of RELA is ICAM expression, which is also regulated by osteopontin [26,27]. Osteopontin is co-expressed with CD44 [28], which co-localizes with annexin A2 [29]. Moreover, there are links between NFKB1 and the expression of CASP3 [30,31]. CASP3 and BAX are upregulated during apoptosis, while BCL2 is downregulated [32]. After the PF maneuvers, we measured increases in CASP3 and a reduction of BCL2 mRNAs, but no changes in their protein products and no signs of apoptosis. In addition, we detected an upregulation of ERK1 after P1 compared to $1 \mathrm{~g}$, ERK2 after P31 compared to P1 samples, and FAK1 after P31 compared to $1 g$, whereas PRKCA and RAF1 remained unchanged in short-term $\mu g$. Moreover, the JNK1 gene expression was down-regulated after the first parabola and unaltered after P31 compared to $1 \mathrm{~g}$.

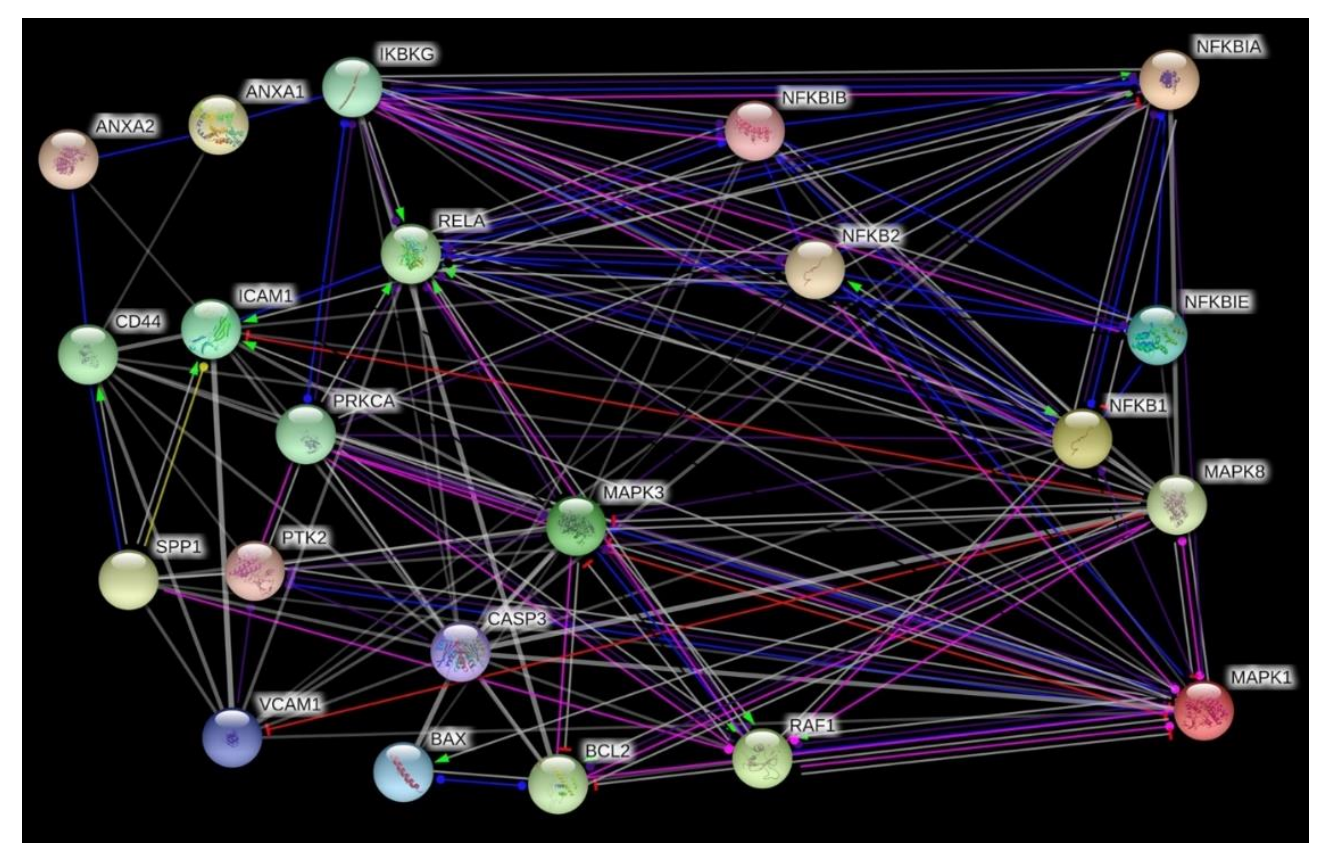

Figure 9. Network of the functional interaction of genes and their products analyzed in this study. The analysis was performed by STRING (Search Tool for the Retrieval of Interacting Genes/Proteins) v11.0) provided by the STRING Consortium (Available online: https://string-db.org/). The result is presented in the molecule action mode. Gene names are indicated. 


\section{Discussion}

The basal-like or triple-negative form of breast cancer refers to tumors not expressing the $E R, P R$, $A R$ and HER2 genes [1]. This breast cancer type is very heterogeneous, which complicates treatment. The MDA-MB-231 cell line was isolated from a pleural effusion of a patient with invasive ductal carcinoma and is ER-, PR-, and E-cadherin negative and expresses mutated p53. Microarray profiling revealed that the MDA-MB-231 cell genome clusters with the basal subtype of breast cancer. In addition, MDA-MB-231 cell lack HER2 and thus this cell line is a good model of TNBC [8,33,34].

Gravity is permanently influencing the human body and all life on Earth. Gravitational unloading results in enormous changes in the organism, organs, tissues and cells [35,36].

Microgravity induces a large number of changes in thyroid and breast cancer cells, such as alterations of the cytoskeleton, extracellular matrix, focal adhesion, growth behavior, differentiation, proliferation, cell adhesion or an increased apoptosis [15,20,37-40].

We recently exposed MCF-7 breast cancer cells to the RPM and detected 3D MCS formation within $24 \mathrm{~h}$ [20]. The pathway analysis of 47 examined genes proposed that NF- $\mathrm{kB}$ variants are involved in the formation of MCS [20]. This finding was in agreement with data obtained earlier from thyroid cancer studies [19]. Poorly differentiated FTC-133 follicular thyroid cancer cells cultured on an RPM for $24 \mathrm{~h}$ showed higher levels of NF-kB-p65 protein and apoptosis than $1 \mathrm{~g}$-controls [19]. Both studies indicated an involvement of NF- $\mathrm{KB}$ in $3 \mathrm{D}$ growth. No information exists about the early phases when cells are exposed to $\mu g$.

We had the opportunity to attend the 29th Deutsches Zentrum für Luft- und Raumfahrt (DLR) PF mission in Bordeaux Merignac, France, and to study cells in r- $\mu g$ (Available online: https://www.dlr. de/rd/desktopdefault.aspx/tabid-2285/3423_read-47055/; https:/www.dlr.de/rd/desktopdefault.aspx/ tabid-2285/3423_read-50372/). We investigated MDA-MB-231 cells in $\mathrm{r}-\mu \mathrm{g}$ during PF maneuvers. The cells were fixed with RNAlater after the first and the 31st parabola, keeping in mind that this last time point represents a mixture of alternated acceleration phases. Postflight we focused on NF-kB signaling, cell adhesion, and apoptosis. Furthermore, cells exposed to an iRPM, hyper- $g$ cultures $(1.8 g)$ and VIB samples were examined to evaluate the impact of these factors on the cells.

\subsection{Influence of Altered Gravity Conditions and Vibration on Cell Survival}

Apoptosis is involved in the pathogenesis of many diseases including among others ischemia, autoimmune and neurodegenerative diseases, as well as in tumor response to chemotherapy and/or radiotherapy [41].

It is known from earlier studies that cancer cells will become apoptotic when exposed to $r-\mu g$ and $\mathrm{s}-\mu \mathrm{g}$ and that apoptosis is involved in cell detachment and formation of spheroids [19]. Therefore, we investigated $C A S P 3, A N X A 1, A N X A 2, B A X$ and $B C L 2$ mRNA expression patterns.

In our short-term experiments, after a 2-h exposure to s- $\mu g$, hyper- $g$ or vibration, TUNEL staining of TNBC cells revealed no signs of apoptosis and $100 \%$ viable cells. The gene expression of CASP3 was elevated after the first and 31st parabola, but no uncleaved caspase- 3 was detectable and no detectable cleavage of caspase- 3 occurred. The CASP3 gene expression was not changed in VIB-, hyper-g- and $\mathrm{s}-\mu g$-samples. This is in agreement with earlier findings obtained with endothelial cells exposed to PF maneuvers [42]. Furthermore, the gene expression of CASP3 and ANXA2 was reduced in endothelial cells exposed to a two-hour period of VIB or hyper- $g$ conditions [43]. In MDA-MB-231 cells ANXA1 mRNAs were not changed during the parabolic flight, hyper- $g-$, s- $\mu g$ - and VIB-exposure. However, ANXA2 protein after PFC as well as ANXA2 mRNA expression after s- $\mu g$ exposure was significantly altered. Thus, $\mu g$ has an impact on cell survival that is highly dependent on the cell type as well as on the duration of exposure. 


\subsection{Impact of Real Microgravity on NF- $\kappa B$ Signalling in TNBC}

$\mathrm{NF}-\mathrm{KB}$ is an interesting factor because it is associated with spaceflight-related health problems. Activation of NF- $\mathrm{KB}$ is frequently observed in breast cancer as well. An NFKB3 overexpression indicates increased aggressiveness of breast cancer and a poor prognosis [44]. In addition, NF- $\mathrm{kB}$ is involved in endocrine therapy resistance [45]. Activation of NF- $\mathrm{kB}$ promotes the survival of tumor cells. Several gene products that negatively regulate apoptosis in tumor cells are controlled by NF- $\mathrm{kB}$ activation.

The NF- $\mathrm{kB}$ proteins include the different variants NF- $\mathrm{kB}-\mathrm{p} 50,-\mathrm{p} 52$ and -p65, which are encoded by the gene loci NFKB1, 2 and 3 [45]. These proteins are bound and inhibited by I $K B$ proteins. The effectors and inhibitors are activated by external triggers and, thus, interesting in $\mu g$-based research.

Human adherent cells exposed to s- $\mu g$ on a RPM showed elevated levels of NF- $k B$ p 65 protein compared with $1 \mathrm{~g}$-controls, a result found earlier in endothelial cells and in FTC-133 follicular thyroid cancer cells $[19,46]$.

NF- $\mathrm{KB}$ exerts several transcriptional regulatory functions important for programmed cell death [47] and is inactivated by binding to I $\kappa \mathrm{B}$ (inhibitor of NFkB).

The NFKB1 (Nuclear Factor Kappa B Subunit 1) mRNA was significantly elevated after the 31st parabola compared to $1 g$, no changes were measured for the NFKB2 (Nuclear Factor Kappa B Subunit 2) mRNA at each time point and an upregulated gene was found for NFKB3 (RELA Proto-Oncogene (V-Rel Avian Reticuloendotheliosis Viral Oncogene Homolog A), Nuclear Factor NF-Kappa-B P65 Subunit) after the first parabola. NFKB3 mRNA was unaltered after the last parabola (P31). Despite this result, the corresponding protein NF-KB p65 was down-regulated after the first and 31st parabola. This counterregulatory effect was not due to VIB or hyper-g occurring during the PF (Figure 3E,F), as the NFKB3 gene expression was unchanged in VIB and $1.8 \mathrm{~g}$ samples. The normalization of NFKB3 after 31 parabolas and the down-regulation of NF- $\mathrm{kB}$ p 65 protein in short-term $\mathrm{r}-\mu \mathrm{g}$ (after one parabola, that means $22 \mathrm{~s}$ of $\mathrm{r}-\mu g$ ) is in agreement with earlier microarray data obtained from activated $\mathrm{T}$ cells cultured in space, which showed a suppressed expression of c-REL and NF-kB gene targets after $1.5 \mathrm{~h}$ [48]. In addition, a four-hour exposure on the RPM of activated T cells revealed a suppressed expression of NF- $\mathrm{kB}$ gene targets [49].

In many cell types, NF- $\kappa B$ dimers are located in the cytoplasm in an inactive form through association with any of several IKB inhibitor proteins (IKB $\alpha,-\beta,-\varepsilon,-\gamma, \mathrm{p} 105$ and $\mathrm{p} 100)$ [50].

The NF- $\kappa B$ signaling pathway is mainly regulated by inhibitor $\kappa B(I \kappa B)$ proteins and the I $\mathrm{B}$ kinase complex through two major pathways: the canonical and non-canonical NF- $\mathrm{KB}$ pathways [50]. We measured significantly elevated NFKBIA and NFKBIB mRNAs after the 31st parabola, whereas the NFKBIE and IKBKG gene expression were not altered by $r-\mu g$ (Figure 2). VIB did not affect the family of cellular IкB proteins inhibiting the NF- $\kappa B$ transcription factors, but hyper-g elevated the NFKBIA mRNA expression indicating that the measured elevation may be due to the hyper- $g$ phase of the parabola, because an iRPM-exposure of the MDA-MB-231 cells demonstrated no changes in NF-KB signaling. On the iRPM all investigated genes remained stably expressed. The RPM aims to simulate near weightlessness, but one should take note of increased fluid movements-and thus shear forces-occurring in the flasks, when the device is used for cell cultures experiments [51]. First, it is important to place the sample as close as possible to the center of rotation in order to minimize residual g-artifacts and second, the cell culture flasks have to be completely filled with medium without air bubbles to minimize shear stress. The RPM is used to prepare spaceflight missions and for tissue engineering purposes. It has proven to be a useful device for long-term cultures of cancer cells and benign cells [14]. Postflight data revealed that genes and proteins involved in the regulation of thyroid cancer cell proliferation and metastasis were similarly regulated under RPM and spaceflight conditions [52].

\subsection{Parabolic Flight Maneuvers Changed Cell Adhesion Factors}

It is known that s- $\mu g$ conditions induced changes in the cytoskeleton, ECM, and focal adhesion factors in various cell types [53,54]. Long-term RPM-exposure of human endothelial cells induced the 
formation of 3D tubular structures and spheroids [55]. In parallel, secretion of the factors ICAM-1, and VCAM-1 were both increased, when the influence of gravity is minimized for 35 days [55]. In MDA-MB-231 cells exposed to short-term $\mu g$ on a parabolic flight, an increased synthesis of ICAM-1 protein was found after the P31. A similar result was measured for VCAM-1 protein as given in Figure 6.

The adhesion molecules ICAM-1 and VCAM-1 are mediating the cell adhesion of cancer cells, lymphocytes and other cells to the vascular endothelium [56]. Moreover, ICAM-1 is involved in angiogenesis and is able to increase the survival of microvessels [57].

Primary human macrophages differentiated from monocytes exposed to 11 days $r-\mu g$ in space on the ISS revealed a reduced surface expression of ICAM-1, defucosylation of surface proteins and an altered metabolite spectrum [58]. Another study examined the ICAM-1 protein synthesis and ICAM1 gene expression in cells of the monocyte/macrophage system exposed to $\mathrm{r}$ - and $\mathrm{s}-\mu \mathrm{g}$ obtained during 2D clinostat, parabolic flight, sounding rocket, and orbital experiments [59]. Murine BV-2 microglial cells showed a downregulated ICAM1 expression, when exposed to a 2D clinostat and a rapid and reversible downregulation in the $\mu g$-phase of PF maneuvers [59].

Interestingly, an elevated ICAM1 mRNA was measured in macrophage-like differentiated human U937 cells during the $\mu g$-phase of PFs. In non-differentiated U937 cells, no effect of $\mu g$ was observed [59].

In addition, we studied the early effects of hyper- $g$, and VIB comparable to the conditions that occur during PFs on the gene expression of ICAM1 and VCAM1. Both vibration and hypergravity had no effect on VCAM1 expression. Hyper-g did not change the ICAM1 mRNA expression, while VIB-exposure of the MDA-MB-231 cells revealed a non-significant result due to the high variation. Furthermore, the SPP1 gene expression was not altered by VIB and hyper- $g$, whereas CD44 was unchanged by VIB, but significantly elevated by hyper-g. Therefore, it can be assumed that the elevated CD44 gene and protein expression after P31 (Figure 6G,H) is mainly due to hyper-g (Figure 7G). Comparable results were obtained when poorly differentiated ML-1 follicular thyroid cancer cells were investigated during a PFC. The SPP1 mRNA was significantly elevated after P31 [60]. The SPP1 gene expression was not changed by VIB and hyper-g in ML1 follicular thyroid cancer cells [60]. Corresponding data were obtained when human chondrocytes were studied during PF maneuvers [61]. No significant changes in the gene expression levels were observed during VIB and hyper-g experiments [61].

In a next step, we focused on the cell-surface glycoprotein CD44 antigen, which is involved in cell adhesion, migration and cell-cell interactions. The CD44 is a receptor for hyaluronic acid and interacts with osteopontin. The mRNA expression of $C D 44$ and the corresponding protein content were both significantly elevated after P1 and P31 compared to $1 \mathrm{~g}$. Similar results were obtained earlier, when cells were exposed to a NASA rotary cell culture system (RCCS) grown as 3D spheroids and were CD44-positive [62]. The CD44-positivity of the cells grown in 3D MCS was determined by immunocytochemistry and was elevated in bladder cancer, prostate cancer, and glioma cell lines compared with $1 \mathrm{~g}$-cultures [62].

Rat osteoblasts cultured for 4 or 5 days aboard the Space Shuttle and solubilized during spaceflight revealed strongly elevated CD44 mRNA levels in the flight cultures [63]. In addition, FTC-133 follicular thyroid cancer cells exposed to an RPM for $24 \mathrm{~h}$ expressed a CD44 mRNA which was significantly up-regulated in adherent cells but not significantly altered in MCS [19]. In addition, an increase in SPP1 mRNA was measured in adherent FTC-133 cells cultured on the RPM. CD44 can also interact with SPP1. The SPP1 mRNA was elevated in MDA-MB-231 cells after P31 compared with P1 and 1 $g$-samples. The synthesis of the protein was reduced during the PF maneuvers (Figure $6 \mathrm{~F}$ ), whereas both hyper- $g$ and VIB stress had no effect on SPP1. These results are in concert with data obtained from thyroid cancer cells exposed to the RPM. Simulated $\mu g$ reduced the amount of osteopontin in adherent cells and MCS. Based on the role of osteopontin as a mediator of cell-matrix adhesion and communication, it is influencing tumorigenesis and invasion [64]. Osteopontin seems to be involved in motility regulation by interaction with CD44 in colon cancer cells, which suggests a role for osteopontin 
in cancer progression [65]. Osteopontin is a potential cancer biomarker [66] and is involved in biological processes such as cell proliferation, survival, angiogenesis, progression and metastasis [66].

Another study demonstrated that in MDA-MB-231 cells, the inhibition of NF-kB via the chemical compound Bay-11-7082 results in a CD44 suppression [67]. The NF-kB inhibition and subsequent CD44 suppression reduced the cell proliferation and invasiveness of breast cancer cells. In contrast in $\mu g$, the cells reacted with a down-regulation of NF-kB p65 protein and an increase in CD44, a finding which has to be investigated in long-term $\mu g$-studies in the future.

\subsection{Interaction Network of Selected Genes Evaluated by STRING Analysis}

The interaction between CD44 and osteopontin as a potential basis for cancer progression and metastasis formation is known for a long time [68]. In this study, the up-regulation of the CD44 mRNA seems to be induced by the hyper- $g$ phases of the PF maneuvers, whereas SPP1 is mainly elevated by $\mathrm{r}-\mu g$. Interestingly, the synthesis of osteopontin is reduced, a finding only observed in r- $\mu g$.

Furthermore, osteopontin regulates the ICAM-1 and VEGFA expression mainly in triple-negative/basal-like breast cancer, supporting its role in tumor progression in TNBC [27]. Osteopontin protein was reduced in P31 samples, whereas the ICAM-1 protein synthesis was elevated after 31 parabolas which may allow for both proteins to conclude a counterregulatory interaction mechanism in short-term $\mu g$.

Another group demonstrated that purified native OPN induces NF- $\mathrm{KB}$ activation and NF-KB-dependent ICAM-1 expression in breast cancer cells [69]. We measured a reduced amount of NF- $k B$ after P1 and P31 which may be due to the reduced osteopontin content (Figure 2D, Figure 6F).

Both cell adhesion molecules ICAM-1 and VCAM-1 are increased in patients with advanced breast cancer and the increase in VCAM-1 is of prognostic significance [70]. In our study the VCAM-1 protein synthesis was elevated after P1 and P31. VCAM1 is one of five genes (CXCL12, MMP2, MMP11, $V C A M 1$, and $M M E$ ), which were associated with tumor progression, angiogenesis, and metastasis [71].

There is also an interaction between CD44 and ANXA2. ANXA1 together with ANXA2 are both associated with the aggressive behavior of TNBC [72]. The prognostic impact of ANXA1 relies on a high ANXA2 expression and both are preferential for TNBC [72]. The MDA-MB-231 cells exhibited a high expression of ANXA1 and ANXA2. ANXA1 remained stable under all gravity conditions and VIB. Both, r- and s- $\mu g$ induced a reduction of ANXA2 protein after 31 parabolas and ANXA2 expression after $2 \mathrm{~h}$ RPM exposure. This response seems to be due to altered gravity.

ANXA1 is known to constitutively activate NF- $\mathrm{KB}$ in breast cancer cells by interacting with the IKK complex [25], an interaction that might not to be relevant in $\mu g$.

ANXA2 is upregulated in many cancer types and is involved in cancer cell migration, adhesion, invasion, and metastasis [73]. Intracellular annexin A2 regulates NF- $\mathrm{KB}$ signaling by binding to the p50 subunit in a calcium-independent manner [73]. The ANXA2-p50 complex translocated into the nucleus [73]. After the first parabola annexin A2 protein synthesis was elevated and then after the 31st parabola reduced. The NFKB1 mRNA was upregulated after P31, but was not altered under all other experimental conditions (Figure 2A, Figure 3A,B).

MAPK3 (ERK1) was upregulated after the first parabola and is interacting with RELA, CASP3 and $B C L 2$. It is known that NF- $K B$ inhibits ERK activation to enhance cell survival during the development of tumor adaptive radioresistance in breast cancer cells [74]. In addition, ERK1/2 play a key role in controlling the BCL2-regulated, cell-intrinsic apoptotic pathway [75]. Other interactions are found for OPN, FAK and ERK1/2 as well as RELA. Integrin $\alpha v \beta 3$ binding with OPN mediates the signaling pathways of FAK, ERK1/2, and NF-KB to activate cellular migration [66], which is important for the dissemination of cancer cells to distant tissues.

\subsection{MAPK Signaling Factors Involved in Cancer Progression and Metastasis}

We investigated further factors known to enhance cancer growth and spreading. The protein kinase $\mathrm{C}$ alpha $(\mathrm{PKC} \alpha)$ is implicated in cancer progression and associated with a poor prognosis in 
breast cancer patients [76]. There is evidence that PKC $\alpha$ is a key regulator of migration and invasion in endocrine resistant ER+ breast cancer and basal A TNBC, but not in other subtypes such as endocrine sensitive ER+ [76]. In this study, we found a slight increase in PRKCA in TNBP exposed to short-term $\mu g$ after 31 parabolas. This result was not significant, and thus it may be speculated that PRKCA is upregulated later, when the cell detachment starts as well as the 3D aggregation of breast cancer cells [40]. In addition, PRKCA is also a key candidate gene in melanoma metastasis [77]. An important step for metastasis is that protein kinase $\mathrm{C}$ alpha activates RAF-1 by direct phosphorylation [78].

The biological process of the epithelial-mesenchymal transition (EMT) is known to increase migration and spreading of cancer cells, progression of the cell cycle, and resistance to apoptosis and chemotherapy. It supports tumor progression. One important signaling pathway involved in progression and metastasis is the MAPK pathway [79]. Therefore, we determined the RAF1 mRNA expression. RAF1 works as a regulatory link between the membrane-associated Ras GTPases and the MAPK/ERK cascade and functions as a switch determining proliferation, differentiation, apoptosis, survival and oncogenic transformation of human cells [80]. RAF1 activation initiates a mitogen-activated protein kinase (MAPK) cascade [80]. The fact that it remained unaltered might explain that we did not find any apoptosis in TNBC exposed to short-term microgravity (Figure 8B).

Furthermore, we measured the expression of ERK1 and ERK2. The ERK subfamily consists of typical (ERK 1/2/5), and atypical (ERK 3/4/7/8) members. ERKs are involved in the regulation of EMT and are thus promoting tumor progression. The ERK1 gene expression was significantly up-regulated after the first parabola compared to $1 g$-samples, and ERK 2 after the 31st parabola compared with P1 $\mathrm{r}$ - $\mu$ g-samples (Figure 8D). ERK1 seems to give an initial signal to start 3D aggregation in $\mu g$.

Moreover, we focused on the focal adhesion kinase 1 (FAK1), which is also called PTK2 protein tyrosine kinase 2 (PTK2) and known to increase cancer cell migration and promote metastatic dissemination to distant sites [81]. Blocking of FAK revealed that breast cancer cells became less metastatic due to decreased mobility [81]. The FAK1 mRNA was significantly up-regulated after P31 compared to $1 \mathrm{~g}$-samples. This is an interesting result indicating its importance for 3D aggregation, breast cancer progression and invasion. Chan et al. [82] had demonstrated that the depletion of FAK induced the formation of active invadopodia and impaired invasive cell migration.

Finally, we measured the MAPK8/JNK1 mRNA in our experimental $\mu$-dependent approach. The JNK1 gene was down-regulated after the first parabola in the $\mu g$-exposed TNBP cells.

It has been shown that JNK1 promotes cell survival in Her2/neu-positive breast cancer [83]. Human studies have shown the relevance of JNK activation to various human cancers [84]. These kinases are involved in the prevention of malignant transformation via the induction of apoptosis and in promoting cell survival in established tumors [85]. In addition, there is a potential to monitor JNK activity as an early biomarker of response to chemotherapy [85]. Therefore, the decrease in JNK1 mRNA expression seems to promote a following 3D formation of the TNBC cells in real $\mu g$-conditions.

Taken together, TNBC cells exposed to short-term $\mu g$ obtained by PF maneuvers kept all signs of a more aggressive phenotype as elevations of ICAM1 and VCAM1 proteins occurred soon.

MDA-MB-231 cells exposed to short-term $r-\mu g$ were relatively stable to this external stressor, vibration and hyper- $g$.

In summary, an early up-regulation of NFKB1 (P1), NFKB3 (RELA) (P1), ERK1 (P1), ICAM1 (P1), NFKBIA (P31), NFKBIB (P31), FAK1 (P31), SPP1 (P31) and CD44 (P1, P31) gene expression as well as a reduced protein content of NF- $\mathrm{KB}$ p65 and osteopontin were found after the PF maneuvers. CD44 and NFKBIA were upregulated in hyper- $g$, showing that the hyper-g-phase seems to influence both factors. For all other genes, our data indicate that the microgravity phase is the driving factor of most of these changes in gene expression. These results are very important because apoptosis is needed for cell detachment together with an activation of NF-KB-p65 to form 3D growth (spheroids) of cancer cells when they were exposed to $\mu g$. Changes in osteopontin protein suggest a role in survival, angiogenesis, invasion, and metastasis of TNBC cells. 


\section{Materials and Methods}

\subsection{Cell Culture}

MDA-MB-231 cells were purchased from the American Type Culture Collection (ATCC ${ }^{\circledR}$ HTB26 $^{\mathrm{TM}}$, Manassas, Virginia, USA)). They were cultured in RPMI 1640 (Life Technologies, Paisley, UK), 10 \% FCS (Sigma Aldrich, Steinheim, Germany) and 1\% penicillin/streptomycin (Life Technologies, New York, USA). The cells were cultured in vented $775 \mathrm{~cm}^{2}$ flasks (Sarstedt, Nümbrecht, Germany) and were split every 4-5 days to prevent confluence.

\subsection{9th. Parabolic Flight Campaign}

The PFs were organized by the DLR in cooperation with Novespace, Bordeaux-Mérignac Airport, France. The cells were transferred on board of the Airbus A310 (Figure 10A) into a pre-warmed $37^{\circ} \mathrm{C}$ incubator shortly before take-off and they were incubated at $37{ }^{\circ} \mathrm{C}$ for the whole time during the flight. The flight rack is shown in Figure 10B. Each parabola had an initial phase of hyper- $g(1.8 g)$ for $22 \mathrm{~s}$ during pull-up and a final phase of hypergravity for $22 \mathrm{~s}$ during pull-out (Figure 10C). The two hyper-g-phases framed a 22-s long $\mu g$-phase. The flight maneuver was repeated 31 times per flight day. During the PFs, the MDA-MB-231 cells were fixed with RNAlater (Invitrogen by Thermo Fischer Scientific, Vilnius, Lithuania) at the end of the first parabola (P1) and the end of the last parabola (P31). The cells were cultured in $775 \mathrm{~cm}^{2}$ cell culture flasks (Sarstedt, Nümbrecht, Germany ) with $10 \mathrm{~mL}$ medium in each flask. Each flask had a fixed three-way connector on the lid which was connected with $140 \mathrm{~cm}$ tubing to a $50 \mathrm{~mL}$ syringe filled with RNAlater. The RNAlater was injected manually into the flasks at the designated times. Additional MDA-MB-231 cells were incubated on ground to serve as static $1 \mathrm{~g}$-controls. The ground control cells were fixed with RNAlater in parallel to the samples on board of the flight. After landing, the medium and RNAlater mixture was removed and replaced with $5 \mathrm{~mL}$ of fresh RNAlater. The cells were harvested with a $25 \mathrm{~cm}$ scraper (Sarstedt, Nümbrecht, Germany) and stored suspended in RNAlater at $4{ }^{\circ} \mathrm{C}$ in $15 \mathrm{~mL}$ tubes until RNA isolation [54].

\subsection{Vibration Experiments}

As a PF implements different stressors, vibration was tested on the cells using the Vibraplex device (DLR, Cologne, Germany) [61,86]. MDA-MB-231 cells were seeded on $\mu$-Slide VI ibiTreat channel slides (Ibidi, Gräfelfing, Germany) for immunostaining and in $\mathrm{T} 25 \mathrm{~cm}^{2}$ cell culture flasks for RNA isolation. The flasks and the slides were attached to the Vibraplex platform. The Vibraplex was transferred into a $37^{\circ} \mathrm{C}$ incubator. Frequencies between 0.2 to $14 \mathrm{~Hz}$ were produced via the Vibraplex for a two-hour duration. These frequencies resemble the VIB produced during the PF. After the vibration procedure, the cells were fixed with either 4\% PFA for immunostaining or RNAlater for RNA isolation. Ground control slides and flasks were cultured in parallel for comparison.

\subsection{Hyper-g Experiments}

MDA-MB-231 cells were counted and seeded into $\mu$-Slide VI ibiTreat channel slides (Ibidi, Gräfelfing, Germany) comparable to [87] for immunostaining. For RNA isolation T $75 \mathrm{~cm}^{2}$ flasks were used with a confluence of $90 \%$. The flasks and the slides were fixed on swing-out gondolas inside the DLR multi-sample incubator centrifuge (MuSIC) located inside a $37^{\circ} \mathrm{C}$ incubator. The centrifuge was rotating at a constant speed to produce $1.8 \mathrm{~g}$ for $2 \mathrm{~h}$ which is comparable to the hypergravity phases produced during the parabolic flight. The device designed by the DLR, Department of Gravitational Biology, is shown in Figure 10D. At the end of the run, the cells were fixed with either $4 \%$ PFA for immunostaining or RNAlater for RNA isolation. All slides and cell culture flasks were randomly assigned to centrifugation or $1 \mathrm{~g}$-ground controls. 

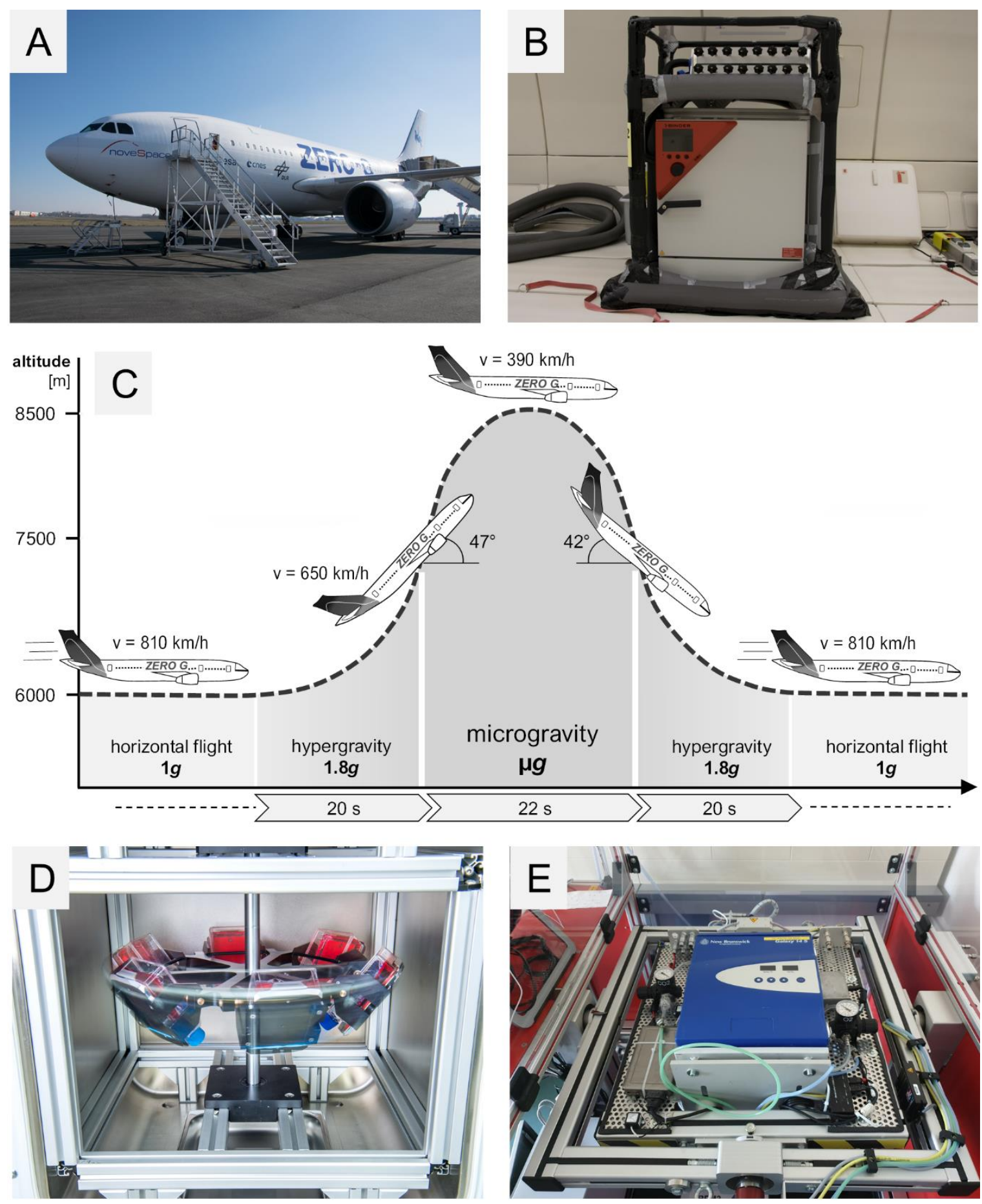

Figure 10. (A) Airbus A310 ZERO-G; (B) Deutsches Zentrum für Luft- und Raumfahrt (DLR) Flight rack; (C) Different phases of a parabolic flight; (D) DLR Multi-sample incubator centrifuge (MuSIC); (E) Incubator random positioning machine (iRPM).

\subsection{Incubator Random Positioning Machine (iRPM)}

The iRPM (Figure 10E) was designed and constructed by Prof. Jörg Sekler-Fachhochschule Nordwestschweiz. Details of the device were published in [88].

MDA-MB-231 cells were seeded in $\mu$-Slide VI ibiTreat channel slides (Ibidi, Gräfelfing, Germany) for immunostaining and $T 25 \mathrm{~cm}^{2}$ flasks for RNA isolation. The slides and the flasks were placed inside a $37^{\circ} \mathrm{C}$ pre-warmed iRPM. At the end of the $2 \mathrm{~h}$, the cells were fixed with either $4 \%$ PFA for 
immunostaining or RNAlater for RNA isolation. The RNA was isolated as mentioned earlier. All the slides and flasks were put in comparison to $1 g$-ground control.

\subsection{RNA Isolation and Quantitative Polymerase Chain Reaction (qPCR)}

All falcon tubes were centrifuged $\left(2500 \times \mathrm{g}\right.$ for $10 \mathrm{~min}$ at $\left.4{ }^{\circ} \mathrm{C}\right)$, followed by discarding the supernatant. The RNA was isolated afterwards using the RNeasy Mini Kit (Qiagen, Hilden, Germany) according to the manufacturer's protocol. The quality of the RNA was evaluated with a spectrophotometer. Afterwards, RNA was converted to cDNA with the High Capacity cDNA reverse Transcription Kit according to the manufacturer's protocol (Applied Biosystems, Darmstadt, Germany). $1 \mu \mathrm{g}$ total RNA in $20 \mu \mathrm{L}$ reaction mix was prepared as stock for qPCR. The primers were designed using Primer Blast (primer designing tool from NCBI).

A total volume of $13 \mu \mathrm{L}$ SYBR green reaction mix (Applied Biosystems, Darmstadt, Germany) was pipetted in each well in a 96 well plate. $1 \mu \mathrm{L}$ of cDNA was added to each reaction mix with a concentration of $100 \mu \mathrm{M}$ forward and reverse primers. The 7500 Fast Real-Time PCR System (Applied Biosystems, Darmstadt, Germany) was used to determine the transcription level of targeted genes (see Table 1). The program consisted of an initial $20 \mathrm{~s}$ long holding stage of $95^{\circ} \mathrm{C}$ followed by the cycling stage. The cycling stage consisted of 40 cycles of $3 \mathrm{~s}$ at $95^{\circ} \mathrm{C}$ and $30 \mathrm{~s}$ at $60^{\circ} \mathrm{C}$. A melting curve was implemented at the end of each run to verify the primer specificity. The data was collected and analyzed by the $\Delta \Delta C_{\mathrm{T}}$ method. $18 \mathrm{~S}$ rRNA and TBP were used as reference genes.

Table 1. List of primer used during the study. Primer sequences are given in $5^{\prime}$ to $3^{\prime}$ direction.

\begin{tabular}{|c|c|c|}
\hline Factor & Primer Name & Sequence $5^{\prime}-3^{\prime}$ \\
\hline \multirow{2}{*}{ 18S rRNA } & $18 \mathrm{~s}-\mathrm{F}$ & GGAGCCTGCGGCTTAATTT \\
\hline & $18 s-\mathrm{R}$ & CAACTAAGAACGGCCATGCA \\
\hline \multirow{2}{*}{ Annexin A1; ANXA1 } & ANXA1-F & GCCAAAGACATAACCTCAGACACAT \\
\hline & ANXA1-R & GAATCAGCCAAGTCTTCATTCACA \\
\hline \multirow{2}{*}{ Annexin A2; ANXA2 } & ANXA2-F & GGTACAAGAGTTACAGCCCTTATGACA \\
\hline & ANXA2-R & CATGGAGTCATACAGCCGATCA \\
\hline \multirow{2}{*}{$\begin{array}{l}\text { BCL2 Associated X, Apoptosis } \\
\text { Regulator; BAX }\end{array}$} & Bax-F & GTCAGCTGCCACTCGGAAA \\
\hline & Bax-R & AGTAACATGGAGCTGCAGAGGAT \\
\hline \multirow{2}{*}{ B-cell lymphoma 2; BCL2 } & $\mathrm{Bcl} 2-\mathrm{F}$ & TCAGAGACAGCCAGGAGAAATCA \\
\hline & Bcl2-R & CCTGTGGATGACTGAGTACCTGAA \\
\hline \multirow{2}{*}{ Caspase 3; CASP3 } & Casp3-F & CTCCAACATCGACTGTGAGAAGTT \\
\hline & Casp3-R & GCGCCAGCTCCAGCAA \\
\hline \multirow{2}{*}{ CD44 } & CD44-F & АСССТССССТСАТТСАССАТ \\
\hline & CD44-R & GTTGTACTACTAGGAGTTGCCTGGATT \\
\hline \multirow{2}{*}{$\begin{array}{c}\text { Extracellular signal-regulated kinases 1; } \\
\text { ERK1 }\end{array}$} & ERK1-F & ACCTGCGACCTTAAGATTTGTGA \\
\hline & ERK1-R & AGCCACATACTCCGTCAGGAA \\
\hline \multirow{2}{*}{$\begin{array}{c}\text { Extracellular signal-regulated kinases 2; } \\
\text { ERK2 }\end{array}$} & ERK2-F & TTCCAACCTGCTGCTCAACA \\
\hline & ERK2-R & TCTGTCAGGAACCCTGTGTGAT \\
\hline \multirow{2}{*}{$\begin{array}{c}\text { Focal adhesion kinase } 1 \\
\text { (Protein-tyrosine kinase 2); pan-FAK1 }\end{array}$} & FAK1-F & TGTGGGTAAACCAGATCCTGC \\
\hline & FAK1-R & CTGAAGCTTGACACCCTCGT \\
\hline \multirow{2}{*}{$\begin{array}{l}\text { Intercellular adhesion molecule } 1 ; \\
\text { ICAM1 }\end{array}$} & ICAM1-F & CGGCTGACGTGTGCAGTAAT \\
\hline & ICAM1-R & CTTCTGAGACCTCTGGCTTCGT \\
\hline
\end{tabular}


Table 1. Cont.

\begin{tabular}{|c|c|c|}
\hline Factor & Primer Name & Sequence $5^{\prime}-3^{\prime}$ \\
\hline \multirow{2}{*}{$\begin{array}{l}\text { Mitogen-activated protein kinase } 8 \\
\text { (MAPK8) (JNK1-a2); MAPK8/JNK1 }\end{array}$} & JNK1-F & TCTCCTTTAGGTGCAGCAGTG \\
\hline & JNK1-R & CAGAGGCCAAAGTCGGATCT \\
\hline \multirow{2}{*}{$\begin{array}{c}\text { NF-kappa-B transcription complex } \\
\text { P105/P50; NFKB1 }\end{array}$} & NFkB1-F & CTTAGGAGGGAGAGCCCAC \\
\hline & NFkB1-R & TGAAACATTTGTTCAGGCCTTC \\
\hline \multirow{2}{*}{$\begin{array}{c}\text { NF-kappa-B transcription complex } \\
\text { P100/P52; NFKB2 }\end{array}$} & NFkB2-F & GTACAAAGATACGCGGACCC \\
\hline & NFkB2-R & CCAGACCTGGGTTGTAGCA \\
\hline \multirow{2}{*}{$\begin{array}{l}\text { NF-kappa-B transcription complex P65; } \\
\text { NFKB P65 }\end{array}$} & NFkB P65-F & CGCTTCTTCACACACTGGATTC \\
\hline & NFkB P65-R & ACTGCCGGGATGGCTTCT \\
\hline \multirow{2}{*}{$\begin{array}{l}\text { NF-kappa-B essential modulator } \\
\text { (NEMO); IKBKG }\end{array}$} & IkBKG-F & AACTGGGACTTTCTCGGAGC \\
\hline & IkBKG-R & GGCAAGGGCTGTCAGCAG \\
\hline \multirow{2}{*}{ NF-kappa-B inhibitor alpha; NFKBIA } & NFkBIa-F & AATGCTCAGGAGCCCTGTAAT \\
\hline & NFkBIa-R & CTGTTGACATCAGCCCCACA \\
\hline \multirow{2}{*}{ NF-kappa-B inhibitor beta; NFKBIB } & NFkBIb-F & CCCGGAGGACCTGGGTT \\
\hline & NFkBIb-R & GCAGTGCCGTGTCCCC \\
\hline \multirow{2}{*}{ NF-kappa-B inhibitor epsilon; NFKBIE } & NFkBIe-F & TGGGCATCTCATCCACTCTG \\
\hline & NFkBIe-R & ACAAGGGATTCCTCAGTCAGGT \\
\hline \multirow{2}{*}{ Protein kinase $\mathrm{C}$ alpha type; PRKCA } & PRKCA-F & TGGGTCACTGCTCTATGGACTTATC \\
\hline & PRKCA-R & CGCССССТСTTCTCAGTGT \\
\hline \multirow{2}{*}{ TATA-box binding protein; TBP } & TBP-F & GTGACCCAGCATCACTGTTTC \\
\hline & TBP-R & GCAAACCAGAAACCCTTGCG \\
\hline \multirow{2}{*}{$\begin{array}{l}\text { Raf-1 Proto-Oncogene, Serine/Threonine } \\
\text { Kinase; Raf1 }\end{array}$} & Raf1-F & GGGAGCTTGGAAGACGATCAG \\
\hline & Raf1-R & ACACGGATAGTGTTGCTTGTC \\
\hline \multirow{2}{*}{ Osteopontin (OPN); SPP1 } & SPP1-F & CGAGGTGATAGTGTGGTTTATGGA \\
\hline & SPP1-R & CGTCTGTAGCATCAGGGTACTG \\
\hline \multirow{2}{*}{$\begin{array}{l}\text { Vascular cell adhesion protein } 1 ; \\
\text { VCAM1 }\end{array}$} & VCAM1-F & CATGGAATTCGAACCCAAACA \\
\hline & VCAM1-R & GGCTGACCAAGACGGTTGTATC \\
\hline
\end{tabular}

\subsection{Western Blotting}

Western blot analysis, gel electrophoresis, trans-blotting, and densitometry were carried out following routine protocols as described previously [21,54,61]. Following lysis and centrifugation, aliquots of $30 \mu g$ were subjected to sodium dodecyl sulphate-polyacrylamide gel electrophoresis (SDS-PAGE) and Western blotting. The samples were collected at the end of the P1 and P31 and were compared to $1 \mathrm{~g}$ control samples. Each condition is represented with 5 samples with a total number of 15 samples for all the conditions per cell line. The samples were loaded onto Criterion XT 4-12\% precast gels (Bio-Rad, Hercules, CA, USA) and run for $1 \mathrm{~h}$ at $150 \mathrm{~V}$. Proteins were then transferred with a TurboBlot (Bio-Rad) (100 V, $30 \mathrm{~min}$ ) to a PVDF membrane. Cofilin-1 was used as a loading control. Membranes were then blocked for $2 \mathrm{~h}$ in TBS-T containing 0.3\% I Block (Applied Biosystems, Foster City, CA, USA). For the detection of the selected antigens (see Table 2), the membranes were incubated overnight at room temperature in TBS-T and $0.3 \%$ I Block solutions of the antibodies. Following three washing steps of $5 \mathrm{~min}$, the membranes were incubated for a further $2 \mathrm{~h}$ at room temperature with the secondary antibody Horseradish peroxidase (HRP)-linked antibody (Cell Signaling Technology Inc., Danvers, MA, USA) diluted 1:4000 in TBS-T and 0.3\% I-Block. The respective protein bands were 
visualized using Bio-Rad Clarity Western ECL (Bio-Rad) and images were captured with Image Quant LAS 4000 mini (GE Healthcare Life Science, Freiburg, Germany). Images of stained membranes were captured on Syngene PXi 4EZ image analysis system (Synoptics, Cambridge, UK) and analyzed using the ImageJ software for densitometric quantification of the respective bands and total protein load.

Table 2. List of the names, sources, companies, molecular weight and dilutions of all the antibodies that were used for Western blots.

\begin{tabular}{ccccc}
\hline Antibody & kDa & Dilution & Company & Source \\
\hline Annexin 2 & 38 & $1: 1000$ & Abcam \#ab41802 & $\mathrm{Rb}$ \\
\hline NFkBp65 & 65 & $1: 1000$ & Thermo Fisher \#PA1-186 & $\mathrm{Rb}$ \\
\hline IKBKG & 38 & $1: 500$ & Origene \#TA812460 & $\mathrm{MS}$ \\
\hline IkB $\alpha$ NFKBIA & 36 & $1: 1000$ & Invitrogen \#MA5-15132 & $\mathrm{MS}$ \\
\hline Cofilin-1 & 20 & $1: 2000$ & Abcam \#ab 42824 & $\mathrm{Rb}$ \\
\hline CD44 & 80 & $1: 500$ & CST\#5640 & $\mathrm{MS}$ \\
\hline VCAM1 & 110 & $1: 500$ & Sc80431 & $\mathrm{MS}$ \\
\hline Casp 3 & 35 & $1: 800$ & CST\#9662 & $\mathrm{Rb}$ \\
\hline ICAM1 & 90 & $1: 500$ & CST\#4915 & $\mathrm{Rb}$ \\
\hline Osteopontin & 44 & $1: 1000$ & SAB4200018 & $\mathrm{MS}$ \\
\hline
\end{tabular}

\subsection{Terminal Deoxynucleotidyl Transferase dUTP Nick End Labeling (TUNEL) Staining}

The MDA-MB-231 cells were cultured in $\mu$-Slide VI 0.4 ibiTreat Ibidi slides (IBIDI GmbH, Martinsried, Planegg, Germany), exposed to VIB, hyper- $g$ and iRPM and subsequently collected for the detection of apoptosis. The method was published earlier in Lützenberg et al. [89].

TUNEL staining was performed according to the manufacturer's recommendation (Thermo Fisher Scientific, Waltham, Massachusetts, USA; Click-iT TUNEL Alexa Fluor 488 (cat\# C10245)).

The stained cell samples (VIB, hyper- $g$, iRPM and corresponding static $1 g$-controls) were examined utilizing a Leica DM 2000 microscope equipped with an objective with a calibrated magnification of 400× and connected to an external light source, Leica EL 6000 (Leica Microsystems GmbH, Wetzlar, Germany). To obtain positive controls the cells were treated with DNAase before the TUNEL staining.

\subsection{STRING Analysis}

Interactions between proteins were determined using the STRING 10 platform [90]. For each protein, the UniProtKB entry number was inserted in the input form "multiple proteins" and "Homo sapiens" was selected as organism. The resulting network view was downloaded in the molecular action view showing lines between interacting proteins and genes [91].

\subsection{Statistical Analyses}

GraphPad prism 7.01 (GraphPad Software, Inc., California, USA) was used to analyze the data. The nonparametric Mann-Whitney $U$ test was used as a statistical test of significance. The difference between groups was considered significant when the $p$-value was less than $0.05\left({ }^{*} p<0.05\right)$.

\section{Conclusions}

Short-term $r-\mu g$ produced by PF maneuvers induced the gene expression of cell adhesion molecules in triple-negative breast cancer cells. This finding is in agreement with long-term $\mu g$ (s-and r- $\mu g$ ) data with other cell types grown on the NASA-developed high-aspect ratio vessel (HARV) or on the Space Shuttle in space for $4-5$ days $[62,63,92]$. The CD44 upregulation in the $r-\mu g$ - and hyper-g-cultures may be involved in the compensative regulation to counteract cellular apoptosis occurring in $\mu g[93,94]$. 
Cell adhesion molecules and factors of the MAPK pathway are involved in the adaptive response to perturbation of mechanical stress under short-term real microgravity. Overall, our study suggests that a fine balance between NF-kB-p65 and osteopontin gene dosage is required to regulate metastasis, survival and angiogenesis of TNBC cells.

Author Contributions: Parabolic flight campaign: M.Z.N., D.M., T.J.C., S.K., and M.K.; VIB experiment: T.J.B. and M.Z.N.; iRPM experiment: M.Z.N., T.J.B., and hyper-g experiment: C.L., R.H., M.Z.N., S.K., M.K., T.J.B.; Conceptualization, D.G., T.J.C. and S.K.; methodology, S.K., M.Z.N., D.M., T.J.B., and J.S.; Software, T.J.B., M.W., and S.K.; Validation, D.G., T.J.C., S.K., M.K. and D.M.; Formal analysis, M.Z.N., S.K., J.S., and M.W.; Investigation, M.Z.N., and S.K.; Resources, M.I. and R.H.; Writing-Original draft preparation, M.Z.N., S.K., D.G., and M.W.; Project administration, D.G.; funding acquisition, D.G. and M.I.

Funding: This research was funded by the German Space Agency (DLR; BMWi projects 50WB1524; 50WB1924).

Acknowledgments: We would like to thank Katrin Stang, Michael Becker and Markus Braun (German Aerospace Center DLR, Bonn) for their support and for giving us the possibility to attend the 29th DLR Parabolic Flight Campaign in Bordeaux-Mérignac, France.

Conflicts of Interest: The authors declare no conflict of interest.

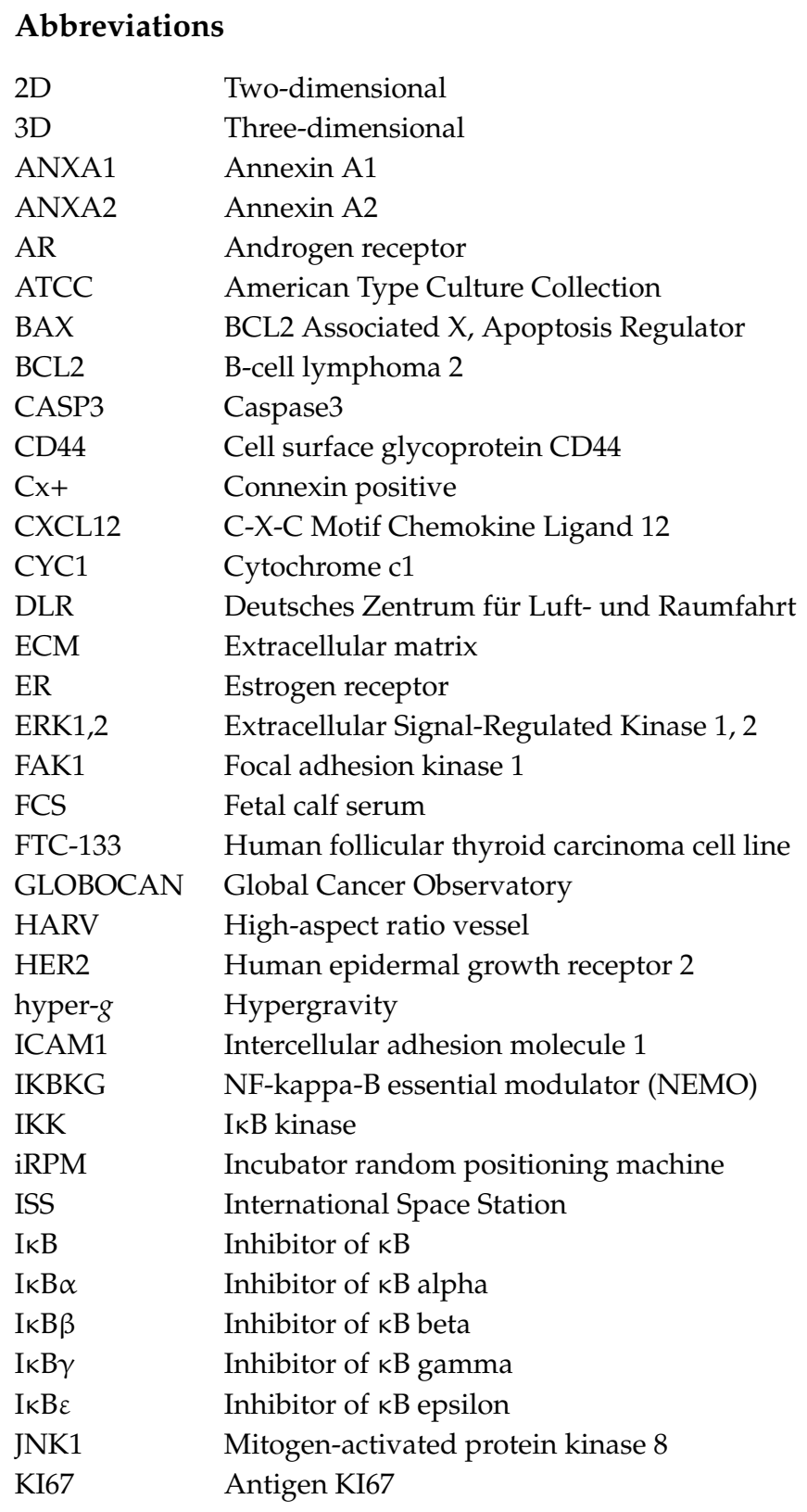




\begin{tabular}{|c|c|}
\hline$\mu g$ & Microgravity \\
\hline MAPK & Mitogen-Activated Protein Kinase \\
\hline MCF-7 & Michigan Cancer Foundation-7 cell line \\
\hline MCS & Multicellular spheroids \\
\hline MDA-MB-231 & M.D. Anderson-Metastasis Breast cancer cell line \\
\hline ML1 & Human thyroid carcinoma cell line \\
\hline MME & Membrane Metalloendopeptidase \\
\hline MMP11 & Matrix Metallopeptidase 11 \\
\hline MMP2 & Matrix Metallopeptidase 2 \\
\hline MuSIC & Multi-sample incubator centrifuge \\
\hline NFKB1 & NF-kappa-B transcription complex P105/P50 \\
\hline NFKB2 & NF-kappa-B transcription complex P100/P52 \\
\hline NFKB3/NFKB & NF-kappa-B transcription complex P65 \\
\hline P65 & \\
\hline NFKBIA & NF-kB-inhibitor-alpha \\
\hline NFKBIB & NF-kB-inhibitor-beta \\
\hline NFKBIE & NF-кB-inhibitor-epsilon \\
\hline NFKB & Nuclear factor-kappaB \\
\hline $\mathrm{P}$ & Parabola \\
\hline PF & Parabolic flight \\
\hline PFA & Paraformaldehyde \\
\hline PR & Progesterone receptor \\
\hline PRKCA & Protein kinase $\mathrm{C}$ alpha \\
\hline PTK2 & Protein tyrosine kinase 2 (known as FAK1) \\
\hline qPCR & Quantitative polymerase chain reaction \\
\hline RAF1 & RAF proto-oncogene serine/threonine-protein kinase \\
\hline$r-\mu g$ & Real microgravity \\
\hline RELA & V-Rel Avian Reticuloendotheliosis Viral Oncogene Homolog A \\
\hline RPM & Random positioning machine \\
\hline $\mathrm{s}-\mu g$ & Simulated microgravity \\
\hline SPP1/OPN & Osteopontin \\
\hline STRING & Search Tool for the Retrieval of Interacting Genes/Proteins \\
\hline TBP & TATA-box binding protein \\
\hline TNBC & Triple-negative breast cancer \\
\hline TUNEL & Terminal deoxynucleotidyl transferase dUTP nick end labeling \\
\hline VCAM1 & Vascular cell adhesion protein 1 \\
\hline VIB & Vibration \\
\hline
\end{tabular}

\section{References}

1. Bray, F.; Ferlay, J.; Soerjomataram, I.; Siegel, R.L.; Torre, L.A.; Jemal, A. Global cancer statistics 2018: GLOBOCAN estimates of incidence and mortality worldwide for 36 cancers in 185 countries. CA Cancer J. Clin. 2018, 68, 394-424. [CrossRef]

2. Van't Veer, L.J.; Dai, H.; van de Vijver, M.J.; He, Y.D.; Hart, A.A.; Mao, M.; Peterse, H.L.; van der Kooy, K.; Marton, M.J.; Witteveen, A.T.; et al. Gene expression profiling predicts clinical outcome of breast cancer. Nature 2002, 415, 530-536. [CrossRef]

3. Soliman, N.A.; Yussif, S.M. Ki-67 as a prognostic marker according to breast cancer molecular subtype. Cancer Biol. Med. 2016, 13, 496-504. [CrossRef] [PubMed]

4. Dai, X.; Li, T.; Bai, Z.; Yang, Y.; Liu, X.; Zhan, J.; Shi, B. Breast cancer intrinsic subtype classification, clinical use and future trends. Am. J. Cancer Res. 2015, 5, 2929-2943. [PubMed]

5. Farmer, P.; Bonnefoi, H.; Becette, V.; Tubiana-Hulin, M.; Fumoleau, P.; Larsimont, D.; Macgrogan, G.; Bergh, J.; Cameron, D.; Goldstein, D.; et al. Identification of molecular apocrine breast tumours by microarray analysis. Oncogene 2005, 24, 4660-4671. [CrossRef] [PubMed] 
6. Prat, A.; Parker, J.S.; Karginova, O.; Fan, C.; Livasy, C.; Herschkowitz, J.I.; He, X.; Perou, C.M. Phenotypic and molecular characterization of the claudin-low intrinsic subtype of breast cancer. Breast Cancer Res. 2010, 12, R68. [CrossRef] [PubMed]

7. Kristensen, T.B.; Knutsson, M.L.; Wehland, M.; Laursen, B.E.; Grimm, D.; Warnke, E.; Magnusson, N.E. Anti-vascular endothelial growth factor therapy in breast cancer. Int. J. Mol. Sci. 2014, 15, 23024-23041. [CrossRef]

8. Cailleau, R.; Young, R.; Olive, M.; Reeves, W.J., Jr. Breast tumor cell lines from pleural effusions. J. Natl. Cancer Inst. 1974, 53, 661-674. [CrossRef]

9. Becker, J.L.; Souza, G.R. Using space-based investigations to inform cancer research on Earth. Nat. Rev. Cancer 2013, 13, 315-327. [CrossRef]

10. Obermaier, C.; Jankowski, V.; Schmutzler, C.; Bauer, J.; Wildgruber, R.; Infanger, M.; Kohrle, J.; Krause, E.; Weber, G.; Grimm, D. Free-flow isoelectric focusing of proteins remaining in cell fragments following sonication of thyroid carcinoma cells. Electrophoresis 2005, 26, 2109-2116. [CrossRef]

11. Pietsch, J.; Kussian, R.; Sickmann, A.; Bauer, J.; Weber, G.; Nissum, M.; Westphal, K.; Egli, M.; Grosse, J.; Schonberger, J.; et al. Application of free-flow IEF to identify protein candidates changing under microgravity conditions. Proteomics 2010, 10, 904-913. [CrossRef] [PubMed]

12. Bauer, J.; Kopp, S.; Schlagberger, E.M.; Grosse, J.; Sahana, J.; Riwaldt, S.; Wehland, M.; Luetzenberg, R.; Infanger, M.; Grimm, D. Proteome Analysis of Human Follicular Thyroid Cancer Cells Exposed to the Random Positioning Machine. Int. J. Mol. Sci. 2017, 18, 546. [CrossRef] [PubMed]

13. Sahana, J.; Nassef, M.Z.; Wehland, M.; Kopp, S.; Kruger, M.; Corydon, T.J.; Infanger, M.; Bauer, J.; Grimm, D. Decreased E-Cadherin in MCF7 Human Breast Cancer Cells Forming Multicellular Spheroids Exposed to Simulated Microgravity. Proteomics 2018, 18, e1800015. [CrossRef] [PubMed]

14. Grimm, D.; Egli, M.; Kruger, M.; Riwaldt, S.; Corydon, T.J.; Kopp, S.; Wehland, M.; Wise, P.; Infanger, M.; Mann, V.; et al. Tissue Engineering Under Microgravity Conditions-Use of Stem Cells and Specialized Cells. Stem Cells Dev. 2018, 27, 787-804. [CrossRef]

15. Masiello, M.G.; Cucina, A.; Proietti, S.; Palombo, A.; Coluccia, P.; D’Anselmi, F.; Dinicola, S.; Pasqualato, A.; Morini, V.; Bizzarri, M. Phenotypic switch induced by simulated microgravity on MDA-MB-231 breast cancer cells. BioMed Res. Int. 2014, 2014, 652434. [CrossRef]

16. Kruger, M.; Melnik, D.; Kopp, S.; Buken, C.; Sahana, J.; Bauer, J.; Wehland, M.; Hemmersbach, R.; Corydon, T.J.; Infanger, M.; et al. Fighting Thyroid Cancer with Microgravity Research. Int. J. Mol. Sci. 2019, 20, 2553. [CrossRef]

17. Wang, W.; Nag, S.A.; Zhang, R. Targeting the NFkappaB signaling pathways for breast cancer prevention and therapy. Curr. Med. Chem. 2015, 22, 264-289. [CrossRef]

18. Zhang, Q.; Lenardo, M.J.; Baltimore, D. 30 Years of NF-kappaB: A Blossoming of Relevance to Human Pathobiology. Cell 2017, 168, 37-57. [CrossRef]

19. Grosse, J.; Wehland, M.; Pietsch, J.; Schulz, H.; Saar, K.; Hubner, N.; Eilles, C.; Bauer, J.; Abou-El-Ardat, K.; Baatout, S.; et al. Gravity-sensitive signaling drives 3-dimensional formation of multicellular thyroid cancer spheroids. FASEB J. 2012, 26, 5124-5140. [CrossRef]

20. Kopp, S.; Sahana, J.; Islam, T.; Petersen, A.G.; Bauer, J.; Corydon, T.J.; Schulz, H.; Saar, K.; Huebner, N.; Slumstrup, L.; et al. The role of NFkappaB in spheroid formation of human breast cancer cells cultured on the Random Positioning Machine. Sci. Rep. 2018, 8, 921. [CrossRef]

21. Murakami, N.; Kuhnel, A.; Schmid, T.E.; Ilicic, K.; Stangl, S.; Braun, I.S.; Gehrmann, M.; Molls, M.; Itami, J.; Multhoff, G. Role of membrane Hsp70 in radiation sensitivity of tumor cells. Radiat. Oncol. 2015, 10, 149. [CrossRef]

22. Oeckinghaus, A.; Hayden, M.S.; Ghosh, S. Crosstalk in NF-kappaB signaling pathways. Nat. Immunol. 2011, 12, 695-708. [CrossRef]

23. Huang, T.; Kang, W.; Zhang, B.; Wu, F.; Dong, Y.; Tong, J.H.; Yang, W.; Zhou, Y.; Zhang, L.; Cheng, A.S.; et al. miR-508-3p concordantly silences NFKB1 and RELA to inactivate canonical NF-kappaB signaling in gastric carcinogenesis. Mol Cancer 2016, 15, 9. [CrossRef]

24. Lindner, V. The NF-kappaB and IkappaB system in injured arteries. Pathobiology 1998, 66, 311-320. [CrossRef]

25. Bist, P.; Leow, S.C.; Phua, Q.H.; Shu, S.; Zhuang, Q.; Loh, W.T.; Nguyen, T.H.; Zhou, J.B.; Hooi, S.C.; Lim, L.H. Annexin-1 interacts with NEMO and RIP1 to constitutively activate IKK complex and NF-kappaB: Implication in breast cancer metastasis. Oncogene 2011, 30, 3174-3185. [CrossRef] 
26. Anwar, K.N.; Fazal, F.; Malik, A.B.; Rahman, A. RhoA/Rho-associated kinase pathway selectively regulates thrombin-induced intercellular adhesion molecule-1 expression in endothelial cells via activation of I kappa B kinase beta and phosphorylation of RelA/p65. J. Immunol. 2004, 173, 6965-6972. [CrossRef]

27. Ortiz-Martinez, F.; Sanmartin, E.; Pomares-Navarro, E.; Perez-Balaguer, A.; Andres, L.; Sanchez-Paya, J.; Aranda, F.I.; Lerma, E.; Peiro, G. Osteopontin Regulates VEGFA and ICAM-1 mRNA Expression in Breast Carcinoma. Am. J. Clin. Pathol. 2015, 143, 812-822. [CrossRef]

28. Ue, T.; Yokozaki, H.; Kitadai, Y.; Yamamoto, S.; Yasui, W.; Ishikawa, T.; Tahara, E. Co-expression of osteopontin and CD44v9 in gastric cancer. Int. J. Cancer 1998, 79, 127-132. [CrossRef]

29. Chintagari, N.R.; Jin, N.; Wang, P.; Narasaraju, T.A.; Chen, J.; Liu, L. Effect of cholesterol depletion on exocytosis of alveolar type II cells. Am. J. Respir. Cell Mol. Biol. 2006, 34, 677-687. [CrossRef]

30. Tiys, E.S.; Ivanisenko, T.V.; Demenkov, P.S.; Ivanisenko, V.A. FunGeneNet: A web tool to estimate enrichment of functional interactions in experimental gene sets. BMC Genom. 2018, 19, 76. [CrossRef]

31. Zaczynska, E.; Kochanowska, I.; Kruzel, M.; Zimecki, M. Lactoferrin Prevents Susceptibility of WEHI 231 Cells to Anti-Ig-Induced Cell Death Promoting Cell Differentiation. Folia Biol. (Praha) 2018, 64, 16-22.

32. Reza, A.; Choi, Y.J.; Yasuda, H.; Kim, J.H. Human adipose mesenchymal stem cell-derived exosomal-miRNAs are critical factors for inducing anti-proliferation signalling to A2780 and SKOV-3 ovarian cancer cells. Sci. Rep. 2016, 6, 38498. [CrossRef]

33. Cailleau, R.; Olive, M.; Cruciger, Q.V. Long-term human breast carcinoma cell lines of metastatic origin: Preliminary characterization. In Vitro 1978, 14, 911-915. [CrossRef]

34. Brinkley, B.R.; Beall, P.T.; Wible, L.J.; Mace, M.L.; Turner, D.S.; Cailleau, R.M. Variations in cell form and cytoskeleton in human breast carcinoma cells in vitro. Cancer Res. 1980, 40, 3118-3129.

35. White, R.J.; Averner, M. Humans in space. Nature 2001, 409, 1115-1118. [CrossRef]

36. Hader, D.P.; Braun, M.; Grimm, D.; Hemmersbach, R. Gravireceptors in eukaryotes-a comparison of case studies on the cellular level. NPJ Microgravity 2017, 3, 13. [CrossRef]

37. Grimm, D.; Bauer, J.; Kossmehl, P.; Shakibaei, M.; Schoberger, J.; Pickenhahn, H.; Schulze-Tanzil, G.; Vetter, R.; Eilles, C.; Paul, M.; et al. Simulated microgravity alters differentiation and increases apoptosis in human follicular thyroid carcinoma cells. FASEB J. 2002, 16, 604-606. [CrossRef]

38. Qian, A.; Zhang, W.; Xie, L.; Weng, Y.; Yang, P.; Wang, Z.; Hu, L.; Xu, H.; Tian, Z.; Shang, P. Simulated weightlessness alters biological characteristics of human breast cancer cell line MCF-7. Acta Astronaut. 2008, 63, 947-958. [CrossRef]

39. Kopp, S.; Warnke, E.; Wehland, M.; Aleshcheva, G.; Magnusson, N.E.; Hemmersbach, R.; Corydon, T.J.; Bauer, J.; Infanger, M.; Grimm, D. Mechanisms of three-dimensional growth of thyroid cells during long-term simulated microgravity. Sci. Rep. 2015, 5, 16691. [CrossRef]

40. Kopp, S.; Slumstrup, L.; Corydon, T.J.; Sahana, J.; Aleshcheva, G.; Islam, T.; Magnusson, N.E.; Wehland, M.; Bauer, J.; Infanger, M.; et al. Identifications of novel mechanisms in breast cancer cells involving duct-like multicellular spheroid formation after exposure to the Random Positioning Machine. Sci. Rep. 2016, 6, 26887. [CrossRef]

41. Schoenberger, J.; Bauer, J.; Moosbauer, J.; Eilles, C.; Grimm, D. Innovative strategies in in vivo apoptosis imaging. Curr. Med. Chem. 2008, 15, 187-194. [CrossRef]

42. Grosse, J.; Wehland, M.; Pietsch, J.; Ma, X.; Ulbrich, C.; Schulz, H.; Saar, K.; Hubner, N.; Hauslage, J.; Hemmersbach, R.; et al. Short-term weightlessness produced by parabolic flight maneuvers altered gene expression patterns in human endothelial cells. FASEB J. 2012, 26, 639-655. [CrossRef]

43. Wehland, M.; Ma, X.; Braun, M.; Hauslage, J.; Hemmersbach, R.; Bauer, J.; Grosse, J.; Infanger, M.; Grimm, D. The impact of altered gravity and vibration on endothelial cells during a parabolic flight. Cell Physiol. Biochem. 2013, 31, 432-451. [CrossRef]

44. Sarkar, D.K.; Jana, D.; Patil, P.S.; Chaudhari, K.S.; Chattopadhyay, B.K.; Chikkala, B.R.; Mandal, S.; Chowdhary, P. Role of NF-kappaB as a Prognostic Marker in Breast Cancer: A Pilot Study in Indian Patients. Indian J. Surg. Oncol. 2013, 4, 242-247. [CrossRef]

45. Khongthong, P.; Roseweir, A.K.; Edwards, J. The NF-KB pathway and endocrine therapy resistance in breast cancer. Endocr. Relat. Cancer 2019, 26, 369-380. [CrossRef]

46. Ulbrich, C.; Westphal, K.; Baatout, S.; Wehland, M.; Bauer, J.; Flick, B.; Infanger, M.; Kreutz, R.; Vadrucci, S.; Egli, M.; et al. Effects of basic fibroblast growth factor on endothelial cells under conditions of simulated microgravity. J. Cell Biochem. 2008, 104, 1324-1341. [CrossRef] 
47. Ghobrial, I.M.; Witzig, T.E.; Adjei, A.A. Targeting apoptosis pathways in cancer therapy. CA Cancer J. Clin. 2005, 55, 178-194. [CrossRef]

48. Chang, T.T.; Walther, I.; Li, C.F.; Boonyaratanakornkit, J.; Galleri, G.; Meloni, M.A.; Pippia, P.; Cogoli, A.; Hughes-Fulford, M. The Rel/NF-kappaB pathway and transcription of immediate early genes in $\mathrm{T}$ cell activation are inhibited by microgravity. J. Leukoc. Biol. 2012, 92, 1133-1145. [CrossRef]

49. Boonyaratanakornkit, J.B.; Cogoli, A.; Li, C.F.; Schopper, T.; Pippia, P.; Galleri, G.; Meloni, M.A.; Hughes-Fulford, M. Key gravity-sensitive signaling pathways drive T cell activation. FASEB J. 2005, 19, 2020-2022. [CrossRef]

50. Gilmore, T.D. Introduction to NF-kappaB: Players, pathways, perspectives. Oncogene 2006, 25, 6680-6684. [CrossRef]

51. Wuest, S.L.; Stern, P.; Casartelli, E.; Egli, M. Fluid Dynamics Appearing during Simulated Microgravity Using Random Positioning Machines. PLoS ONE 2017, 12, e0170826. [CrossRef] [PubMed]

52. Ma, X.; Pietsch, J.; Wehland, M.; Schulz, H.; Saar, K.; Hubner, N.; Bauer, J.; Braun, M.; Schwarzwalder, A.; Segerer, J.; et al. Differential gene expression profile and altered cytokine secretion of thyroid cancer cells in space. FASEB J. 2014, 28, 813-835. [CrossRef] [PubMed]

53. Buken, C.; Sahana, J.; Corydon, T.J.; Melnik, D.; Bauer, J.; Wehland, M.; Kruger, M.; Balk, S.; Abuagela, N.; Infanger, M.; et al. Morphological and Molecular Changes in Juvenile Normal Human Fibroblasts Exposed to Simulated Microgravity. Sci. Rep. 2019, 9, 11882. [CrossRef] [PubMed]

54. Nassef, M.Z.; Kopp, S.; Wehland, M.; Melnik, D.; Sahana, J.; Kruger, M.; Corydon, T.J.; Oltmann, H.; Schmitz, B.; Schutte, A.; et al. Real Microgravity Influences the Cytoskeleton and Focal Adhesions in Human Breast Cancer Cells. Int. J. Mol. Sci. 2019, 20, 3456. [CrossRef]

55. Dittrich, A.; Grimm, D.; Sahana, J.; Bauer, J.; Kruger, M.; Infanger, M.; Magnusson, N.E. Key Proteins Involved in Spheroid Formation and Angiogenesis in Endothelial Cells After Long-Term Exposure to Simulated Microgravity. Cell Physiol. Biochem. 2018, 45, 429-445. [CrossRef]

56. Eibl, R.H.; Benoit, M. Molecular resolution of cell adhesion forces. IEE Proc. Nanobiotechnol. 2004, 151, $128-132$. [CrossRef]

57. Deng, C.; Zhang, D.; Shan, S.; Wu, J.; Yang, H.; Yu, Y. Angiogenic effect of intercellular adhesion molecule-1. J. Huazhong Univ. Sci. Technol. Med. Sci. 2007, 27, 9-12. [CrossRef]

58. Tauber, S.; Lauber, B.A.; Paulsen, K.; Layer, L.E.; Lehmann, M.; Hauschild, S.; Shepherd, N.R.; Polzer, J.; Segerer, J.; Thiel, C.S.; et al. Cytoskeletal stability and metabolic alterations in primary human macrophages in long-term microgravity. PLoS ONE 2017, 12, e0175599. [CrossRef]

59. Paulsen, K.; Tauber, S.; Dumrese, C.; Bradacs, G.; Simmet, D.M.; Golz, N.; Hauschild, S.; Raig, C.; Engeli, S.; Gutewort, A.; et al. Regulation of ICAM-1 in cells of the monocyte/macrophage system in microgravity. BioMed Res. Int. 2015, 2015, 538786. [CrossRef]

60. Ulbrich, C.; Pietsch, J.; Grosse, J.; Wehland, M.; Schulz, H.; Saar, K.; Hubner, N.; Hauslage, J.; Hemmersbach, R.; Braun, M.; et al. Differential gene regulation under altered gravity conditions in follicular thyroid cancer cells: Relationship between the extracellular matrix and the cytoskeleton. Cell Physiol. Biochem. 2011, 28, 185-198. [CrossRef]

61. Aleshcheva, G.; Wehland, M.; Sahana, J.; Bauer, J.; Corydon, T.J.; Hemmersbach, R.; Frett, T.; Egli, M.; Infanger, M.; Grosse, J.; et al. Moderate alterations of the cytoskeleton in human chondrocytes after short-term microgravity produced by parabolic flight maneuvers could be prevented by up-regulation of BMP-2 and SOX-9. FASEB J. 2015, 29, 2303-2314. [CrossRef]

62. Ingram, M.; Techy, G.B.; Saroufeem, R.; Yazan, O.; Narayan, K.S.; Goodwin, T.J.; Spaulding, G.F. Three-dimensional growth patterns of various human tumor cell lines in simulated microgravity of a NASA bioreactor. In Vitro Cell Dev. Biol. Anim. 1997, 33, 459-466. [CrossRef] [PubMed]

63. Kumei, Y.; Morita, S.; Katano, H.; Akiyama, H.; Hirano, M.; Oyha, K.; Shimokawa, H. Microgravity signal ensnarls cell adhesion, cytoskeleton, and matrix proteins of rat osteoblasts: Osteopontin, CD44, osteonectin, and alpha-tubulin. Ann. N. Y. Acad. Sci. 2006, 1090, 311-317. [CrossRef] [PubMed]

64. Weber, G.F. The cancer biomarker osteopontin: Combination with other markers. Cancer Genom. Proteom. 2011, 8, 263-288.

65. Irby, R.B.; McCarthy, S.M.; Yeatman, T.J. Osteopontin regulates multiple functions contributing to human colon cancer development and progression. Clin. Exp. Metastasis 2004, 21, 515-523. [CrossRef] 
66. Wei, R.; Wong, J.P.C.; Kwok, H.F. Osteopontin-A promising biomarker for cancer therapy. J. Cancer 2017, 8, 2173-2183. [CrossRef]

67. Smith, S.M.; Lyu, Y.L.; Cai, L. NF-kappaB affects proliferation and invasiveness of breast cancer cells by regulating CD44 expression. PLoS ONE 2014, 9, e106966. [CrossRef]

68. Weber, G.F.; Ashkar, S.; Cantor, H. Interaction between CD44 and osteopontin as a potential basis for metastasis formation. Proc. Assoc. Am. Physicians 1997, 109, 1-9.

69. Ahmed, M.; Kundu, G.C. Osteopontin selectively regulates p70S6K/mTOR phosphorylation leading to NF-kappaB dependent AP-1-mediated ICAM-1 expression in breast cancer cells. Mol. Cancer 2010, 9, 101. [CrossRef]

70. O’Hanlon, D.M.; Fitzsimons, H.; Lynch, J.; Tormey, S.; Malone, C.; Given, H.F. Soluble adhesion molecules (E-selectin, ICAM-1 and VCAM-1) in breast carcinoma. Eur. J. Cancer 2002, 38, 2252-2257. [CrossRef]

71. Lee, J.Y.; Park, K.; Lee, E.; Ahn, T.; Jung, H.H.; Lim, S.H.; Hong, M.; Do, I.G.; Cho, E.Y.; Kim, D.H.; et al. Gene Expression Profiling of Breast Cancer Brain Metastasis. Sci. Rep. 2016, 6, 28623. [CrossRef] [PubMed]

72. Gibbs, L.D.; Vishwanatha, J.K. Prognostic impact of AnxA1 and AnxA2 gene expression in triple-negative breast cancer. Oncotarget 2018, 9, 2697-2704. [CrossRef] [PubMed]

73. Jung, H.; Kim, J.S.; Kim, W.K.; Oh, K.J.; Kim, J.M.; Lee, H.J.; Han, B.S.; Kim, D.S.; Seo, Y.S.; Lee, S.C.; et al. Intracellular annexin A2 regulates NF-kappaB signaling by binding to the p50 subunit: Implications for gemcitabine resistance in pancreatic cancer. Cell Death Dis. 2015, 6, e1606. [CrossRef] [PubMed]

74. Ahmed, K.M.; Dong, S.; Fan, M.; Li, J.J. Nuclear factor-kappaB p65 inhibits mitogen-activated protein kinase signaling pathway in radioresistant breast cancer cells. Mol. Cancer Res. 2006, 4, 945-955. [CrossRef]

75. Cook, S.J.; Stuart, K.; Gilley, R.; Sale, M.J. Control of cell death and mitochondrial fission by ERK1/2 MAP kinase signalling. FEBS J. 2017, 284, 4177-4195. [CrossRef]

76. Pham, T.N.D.; Perez White, B.E.; Zhao, H.; Mortazavi, F.; Tonetti, D.A. Protein kinase C alpha enhances migration of breast cancer cells through FOXC2-mediated repression of p120-catenin. BMC Cancer 2017, 17, 832. [CrossRef]

77. Chen, J.; Wu, F.; Shi, Y.; Yang, D.; Xu, M.; Lai, Y.; Liu, Y. Identification of key candidate genes involved in melanoma metastasis. Mol. Med. Rep. 2019, 20, 903-914. [CrossRef]

78. Kolch, W.; Heidecker, G.; Kochs, G.; Hummel, R.; Vahidi, H.; Mischak, H.; Finkenzeller, G.; Marme, D.; Rapp, U.R. Protein kinase C alpha activates RAF-1 by direct phosphorylation. Nature 1993, 364, $249-252$. [CrossRef]

79. Olea-Flores, M.; Zuniga-Eulogio, M.D.; Mendoza-Catalan, M.A.; Rodriguez-Ruiz, H.A.; Castaneda-Saucedo, E.; Ortuno-Pineda, C.; Padilla-Benavides, T.; Navarro-Tito, N. Extracellular-Signal Regulated Kinase: A Central Molecule Driving Epithelial-Mesenchymal Transition in Cancer. Int. J. Mol. Sci. 2019, 20, 2885. [CrossRef]

80. Eblen, S.T. Extracellular-Regulated Kinases: Signaling From Ras to ERK Substrates to Control Biological Outcomes. Adv. Cancer Res. 2018, 138, 99-142. [CrossRef]

81. Crapoulet, N.; O'Brien, P.; Ouellette, R.J.; Robichaud, G.A. Coordinated expression of Pax-5 and FAK1 in metastasis. Anticancer Agents Med. Chem. 2011, 11, 643-649. [CrossRef] [PubMed]

82. Chan, K.T.; Cortesio, C.L.; Huttenlocher, A. FAK alters invadopodia and focal adhesion composition and dynamics to regulate breast cancer invasion. J. Cell Biol. 2009, 185, 357-370. [CrossRef] [PubMed]

83. Han, J.S.; Crowe, D.L. Jun amino-terminal kinase 1 activation promotes cell survival in ErbB2-positive breast cancer. Anticancer Res. 2010, 30, 3407-3412. [PubMed]

84. Zhang, J.Y.; Selim, M.A. The role of the c-Jun N-terminal Kinase signaling pathway in skin cancer. Am. J. Cancer Res. 2012, 2, 691-698.

85. Ashenden, M.; van Weverwijk, A.; Murugaesu, N.; Fearns, A.; Campbell, J.; Gao, Q.; Iravani, M.; Isacke, C.M. An In Vivo Functional Screen Identifies JNK Signaling As a Modulator of Chemotherapeutic Response in Breast Cancer. Mol. Cancer Ther. 2017, 16, 1967-1978. [CrossRef]

86. Lutzenberg, R.; Solano, K.; Buken, C.; Sahana, J.; Riwaldt, S.; Kopp, S.; Kruger, M.; Schulz, H.; Saar, K.; Huebner, N.; et al. Pathway Analysis Hints Towards Beneficial Effects of Long-Term Vibration on Human Chondrocytes. Cell Physiol. Biochem. 2018, 47, 1729-1741. [CrossRef]

87. Corydon, T.J.; Kopp, S.; Wehland, M.; Braun, M.; Schutte, A.; Mayer, T.; Hulsing, T.; Oltmann, H.; Schmitz, B.; Hemmersbach, R.; et al. Alterations of the cytoskeleton in human cells in space proved by life-cell imaging. Sci. Rep. 2016, 6, 20043. [CrossRef] 
88. Benavides Damm, T.; Walther, I.; Wuest, S.L.; Sekler, J.; Egli, M. Cell cultivation under different gravitational loads using a novel random positioning incubator. Biotechnol. Bioeng. 2014, 111, 1180-1190. [CrossRef]

89. Lutzenberg, R.; Wehland, M.; Solano, K.; Nassef, M.Z.; Buken, C.; Melnik, D.; Bauer, J.; Kopp, S.; Kruger, M.; Riwaldt, S.; et al. Beneficial Effects of Low Frequency Vibration on Human Chondrocytes in Vitro. Cell Physiol. Biochem. 2019, 53, 623-637. [CrossRef]

90. Snel, B.; Lehmann, G.; Bork, P.; Huynen, M.A. STRING: A web-server to retrieve and display the repeatedly occurring neighbourhood of a gene. Nucleic Acids Res. 2000, 28, 3442-3444. [CrossRef]

91. Pietsch, J.; Riwaldt, S.; Bauer, J.; Sickmann, A.; Weber, G.; Grosse, J.; Infanger, M.; Eilles, C.; Grimm, D. Interaction of proteins identified in human thyroid cells. Int. J. Mol. Sci. 2013, 14, 1164-1178. [CrossRef] [PubMed]

92. Li, N.; Wang, C.; Sun, S.; Zhang, C.; Lu, D.; Chen, Q.; Long, M. Microgravity-Induced Alterations of Inflammation-Related Mechanotransduction in Endothelial Cells on Board SJ-10 Satellite. Front. Physiol. 2018, 9, 1025. [CrossRef] [PubMed]

93. Fedorchenko, O.; Stiefelhagen, M.; Peer-Zada, A.A.; Barthel, R.; Mayer, P.; Eckei, L.; Breuer, A.; Crispatzu, G.; Rosen, N.; Landwehr, T.; et al. CD44 regulates the apoptotic response and promotes disease development in chronic lymphocytic leukemia. Blood 2013, 121, 4126-4136. [CrossRef] [PubMed]

94. Lewis, M.L.; Reynolds, J.L.; Cubano, L.A.; Hatton, J.P.; Lawless, B.D.; Piepmeier, E.H. Spaceflight alters microtubules and increases apoptosis in human lymphocytes (Jurkat). FASEB J. 1998, 12, 1007-1018. [CrossRef]

(C) 2019 by the authors. Licensee MDPI, Basel, Switzerland. This article is an open access article distributed under the terms and conditions of the Creative Commons Attribution (CC BY) license (http://creativecommons.org/licenses/by/4.0/). 